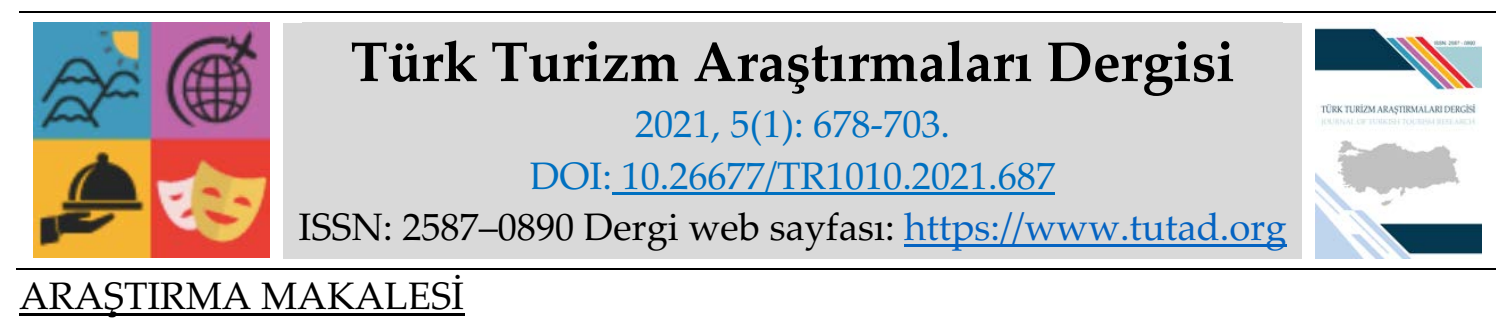

\title{
Turist Rehberlerinin Yorumlayııı Rolünün Turist Destinasyon Sadakati Üzerine Etkisi: Çanakkale Savaşları Gelibolu Tarihi Alan Başkanlığı Örneği*
}

Abidin Can AKTAŞ, Yüksek Lisans Öğrencisi, Balıkesir Üniversitesi, Sosyal Bilimler Enstitüsü, Balıkesir, e-posta: abidincanaktas@gmail.com ORCID: https://orcid.org/0000-0002-6176-3728

Prof. Dr. Özlem KÖROĞLU, Balıkesir Üniversitesi, Turizm Fakültesi, Balıkesir, e-posta: ozlemkoroglu98@yahoo.com

ORCID: https://orcid.org/0000-0002-3974-6120

Öz

Tur esnasında ziyaretçiler ve yerel halk arasında bir köprü görevi gören turist rehberlerinin, turistlere yönelik birçok rolü bulunmaktadır. Bu roller arasında önemli bir yere sahip olanlardan bir tanesi ise yorumlayıcı roldür. Bir bilgiyi direkt olarak vermekten ziyade, bilgiyi anlaşılır kıldıktan sonra tekrar turistlere göre sunmanın etkisi büyüktür. Bu noktada, turist rehberlerinin yorumlayıcı rolünden yola çıkarak, turistlerin destinasyon sadakati üzerinde bir etkisinin olup olmadığı merak konusudur. Bu çalışmanın amacı, turist rehberlerinin yorumlayıcı rolünün turistlerin destinasyon sadakati üzerindeki etkisinin ortaya çıkarılması ve tur sırasında hoş duygular hissinin bir sonucu olabilecek memnuniyet kavramının bu süreçteki aracılık rolünün belirlenmesidir. Bu doğrultuda veriler, araştırma alanını oluşturan Çanakkale Savaşları Gelibolu Tarihi Alanı'nı rehber eşliğinde gezmiş olan 391 misafir üzerinden toplanmıştır. Elde edilen veriler ışığında, turist rehberlerinin yorumlayıcı rolünün turistlerin destinasyon sadakati üzerinde etkili olduğu sonucuna ulaşılmıştır. Turist memnuniyetinin de bu etkide aracılık yaptığı belirlenmiştir.

* Makale Abidin Can AKTAŞ'ın 'Turist Rehberlerinin Yorumlayıcı Rolünün Turist Destinasyon Sadakati Üzerine Etkisi: Çanakkale Savaşları Gelibolu Tarihi Alan Başkanlığı Örneği' adlı tezden türetilmiştir.

Anahtar Kelimeler: Turist Rehberi, Yorumlayıcı Rol, Turist Memnuniyeti, Destinasyon Sadakati. Makale Gönderme Tarihi: 04.01.2021

Makale Kabul Tarihi: 10.03 .2021

Önerilen Atıf:

Aktaş, C. A. ve Köroğlu, Ö. (2021). Turist Rehberlerinin Yorumlayıcı Rolünün Turist Destinasyon Sadakati Üzerine Etkisi: Çanakkale Savaşları Gelibolu Tarihi Alan Başkanlığı Örneği, Türk Turizm Araştırmaları Dergisi, 5(1): 678-703.

(C) 2021 Türk Turizm Araştırmaları Dergisi. 


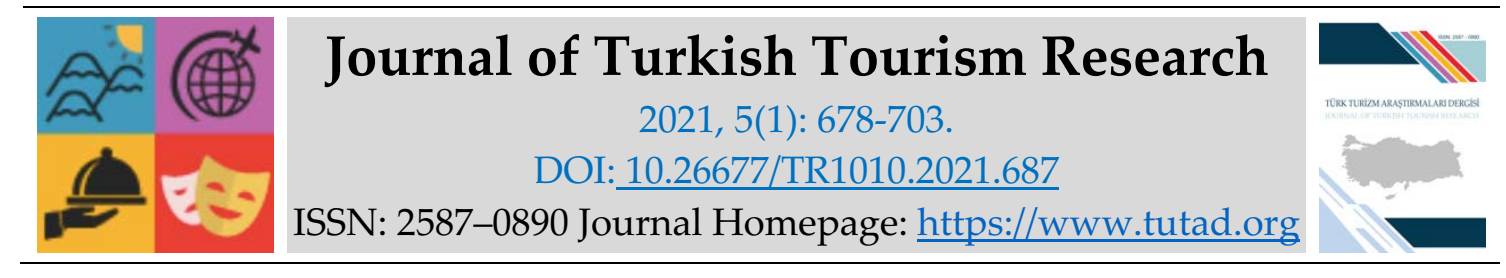

\title{
RESEARCH PAPER
}

\section{Effect of Tour Guide Interpretation Role on Tourist Destination Loyalty: The Case of Directorate of Gallipoli Historic Site}

\begin{abstract}
Abidin Can AKTAŞ, MSc. Student, Balıkesir University, Social Sciences Institute, Balıkesir, email: abidincanaktas@gmail.com

ORCID: https://orcid.org/0000-0002-6176-3728
\end{abstract}

Prof. Dr. Özlem KÖROĞLU, Balıkesir University, Faculty of Tourism, Balıkesir, e-mail: ozlemkoroglu98@yahoo.com

ORCID: https://orcid.org/0000-0002-3974-6120

\begin{abstract}
During the tour, tourist guides, who act as a bridge between visitors and local people, have many roles for tourists. One of the important roles among these roles is the interpretive role. Rather than providing information directly, it has a great effect of presenting the information to the tourists after making it understandable. At this point, it is a question of whether tourists have an impact on destination loyalty, based on the interpretive role of tourist guides. The purpose of this study is to reveal the effect of the interpretative role of tourist guides on tourist destination loyalty and to determine the mediating role of the concept of satisfaction, which can be a result of the feeling of pleasant feelings during the tour. Accordingly, the data were collected from 391 guests who toured the Çanakkale Wars Gallipoli Historical Site, which constitutes the research area, with a guide. In the light of the data obtained from the survey participants, it was concluded that the interpretative role of tourist guides was effective on tourist destination loyalty. It has been determined that tourist satisfaction also plays a mediating role in this effect.
\end{abstract}

Keywords: Tourist Guide, Interpretive Role, Tourist Satisfaction, Destination Loyalty.

Received: 04.01.2021

Accepted: 10.03 .2021

\section{Suggested Citation:}

Aktaş, C. A. and Köroğlu, Ö. (2021). Effect of Tour Guide Interpretation Role on Tourist Destination Loyalty: The Case of Directorate of Gallipoli Historic Site, Journal of Turkish Tourism Research, 5(1): 678-703.

(C) 2021 Türk Turizm Araştırmaları Dergisi. 


\section{Gíriş}

Turist rehberi, beş duyuya hitap eden kişidir. Bir rehber ardından gelen misafirlere, tarih sürecinde o topraklara sahip çıkmış toplumların yaşayış tarzlarını "gösteren", bir tarihi kentin agorasında konuşulan şeylerin "duyulmasını" sağlayan, geçmişten günümüze kadar o topraklarda insanlarla birlikte yaşayan farklı yemeklerin "tadımını" misafirlere tattıran, misafirlerin kendisini gittikleri yere aitmiş gibi "hissettiren" ve o toprakların şimdiye kadar bünyesinde biriktirdiği mitleri, sanatı, efsaneleri ve tarihi "koklatan" kişilerdir (Ulusoy ve Avcikurt, 2019: 75).

Turist rehberlerine tur sırasında farklı görevler düşmektedir. Turu yönetmenin yanı sıra misafirleri memnun etmeye çalışması, gidilen yerlere ait bilgilerin verilmesi, turistler ile yerel halkı buluşturmaya çalışması, farklı tatları ve lezzetleri misafirlerine sunması, zaman yönetimini sağlaması, tedarikçilere yönelik bilgi akışını sağlaması bu görevler arasında görülmektedir. Dolayısıyla rehberlik mesleği kolay bir meslek olarak görülmemelidir. Turist rehberlerinin görevlerine yönelik çeşitli rollere büründükleri söylenebilmektedir. Bunlar, "liderlik", "arabuluculuk", "temsil", "yol göstericilik", "öğretmenlik", "yönetici", "satış elemanı", "kaynak yönetimi" ve "yorumlayıci" gibi rollerdir.

Turist rehberlerinin rolleri içerisinde yer alan yorumlayıcı rolü, en önemli rolleri arasında gösterilmektedir. Rehber yorumlama yöntemiyle bir bilgiyi doğrudan değil farklı turist tiplerine göre farklı şekilde aynı bilgiyi sunmak istemektedir. Bu yöntem turistlerin memnuniyetlerini arttırabilir, konu hakkında bilgi düzeylerini yükseltebilir ve satın aldıkları turdan en yüksek faydayı alabilmelerini sağlayabilir. Özellikle günümüzde tüm turizm paydaşları turistleri kendi bünyesine çekme çabasındayken, rehberlerin bu rolünün önemi oldukça yüksektir. Turist rehberlerinin misafirlere etki edebilmesi hem acentalar hem bölge halkı hem de farklı turizm paydaşlarının yararına görülmektedir. Bu etkiyi yorumlama yöntemiyle yapması turist rehberlerinin de kendilerini geliştirmesini ve sezonluk çalışma süresini tüm yıla yaymasını sağlamaktadır.

Turistlerin bir destinasyona ilk defa gittiklerinde gidilen yer hakkında ilk önce çekicilik unsurlarına baktıkları söylenmektedir. Destinasyona ait çekicilik aynı zamanda iyi bir turizm pazarlaması sunmaktadır. Turistler turları bittiğinde gittikleri destinasyona ait akılda kalıcı şeyleri düşünmektedirler. Bu unsurlar turistleri aynı yere tekrar gitmeye yöneltebilmektedir. Turist döngüsünü yakalayan destinasyonlarda ekonomik açıdan kalkınmalar görülmektedir. Yerel halk ve yerel dükkanlar bu döngüden faydalanmaktadırlar. Dolayısıyla turistleri bir destinasyona yeniden çekmek oldukça önemlidir. İlgili alan yazında bu duruma destinasyon sadakati adı verilmektedir. Turistlerin destinasyon sadakatini oluşturacak unsurların başında rehberlerin geldiği bilinmektedir. Turist rehberleri ziyaretçilere yönelik memnuniyeti sağlaması durumunda, destinasyon sadakatini oluşturduğu düşünülmektedir.

Turist rehberlerinin turistler üzerindeki etkisi oldukça büyüktür. Gerek tur sırasında gerek tur öncesi ve sonrasında turistlere yol gösterip onlarla iletişim halinde kalmaktadırlar. Turist üzerinde etkisi bulunan turist rehberlerinin tur esnasında kullandıkları ifadeleri, sorunlara karşı çözümleri ve bilgilere yönelik yorumları ziyaret gerçekleştiren turistlere karşı görev ve rolleri olduğunun kanıtı niteliğindedir. $\mathrm{Bu}$ noktada, turist rehberlerinin yorum yapabilme yetenekleriyle turistlerin geri ziyaretlerini etkileyip etkilemedikleri veya nasıl etkiledikleri önemli bir soru haline gelmektedir. Turist rehberlerinin yorumlayıcı rolüne ve destinasyon sadakatine yönelik ayrı ayrı birçok çalışma bulunsa da bu iki kavramın birbirleri üzerindeki etkisinin bir arada incelendiği çok az çalışmaya rastlanmaktadır. Bu bağlamda bu araştırmanın hem turizm hem de turist rehberliği literatürüne katkı sağlayacağ turist rehberlerinin kendilerini yorumlama konusunda geliştirmelerine ve paydaşların fikirlerine 
katkıda bulunmasına yol açacağı düşünülmektedir. Turist rehberlerinin rollerine yönelik gelecek çalışmalara da konu bağlamında öncülük edeceği düşünülmektedir.

\section{KURAMSAL ÇERÇEVE}

Gittikçe önemi artan turizm sektörünün içerisinde yer alan her mesleğin, ülke turizmine çeşitli yollardan katkısı ve temsil gücü bulunmaktadır (Güzel, 2007: 12). Bu mesleklerden biri de turist rehberliğidir. Rehber, kılavuz veya yol gösterici şeklinde tanımlanmaktadır (Batman, Yıldırgan ve Demirtaş, 2000: 24). Turist rehberi, turistlere belirli destinasyonları tanıtan, ziyaretçilerin uğradıkları bölgelerin çeşitli özelliklerini ve turizm cazibe unsurlarını anlatan, kısacası bir destinasyonu her bir özelliğiyle sunan ve temsil eden kişidir (Tetik, 2006: 3). Önceden belirlenmiş program dahilinde yabancı veya yerli gezginlere liderlik eden, gidilen programın kapsamına uygun şekilde, ziyaret edilen destinasyonlar hakkında bilgiler aktarmak suretiyle bir bölge veya ülke tanıtımı yapan, ziyaretçilerin kültürel ve sosyo-ekonomik izlenimler edinmesine yardımcı olan kişiler turist rehberleridir (Ahipaşaoğlu, 2006: 121). Bununla birlikte yerli ya da yabancı olsun, turistlere Türkçe veya diğer yabancı dillerde bir ülkenin arkeolojisini, tarihini, doğal güzelliklerini ve kültürünü tanıtan, gezi esnasında turistlere doğru bilgiler veren ve yardımcı olan personel turist rehberleridir (Usta, 1992: 167). Çimrin'e (1995: 9) göre turist rehberi, turistlerle birlikte temas sağlayan, misafirlere eşlik ederek bir ülkenin veya destinasyonun folklorunu, tarihini, sanat eserlerini, türbelerini, anıtlarını, tarihi kalıntılarını tanıtan ve onlar hakkında bilgiler sunan kişidir. Tarihi perspektifte bakıldığında, insanlığın en eski mesleklerinden biri olan rehberlik, iki bin beş yüz yıl öncesinden bugüne kadar, kitle turizminin başlamasıyla birlikte en önemli konumuna ulaşmış bulunmaktadır (Rabotic, 2010: 1). Bu bağlamda turist rehberi, turistler ve varış yerleri konusunda "temel arayüz" olarak tanımlanmaktadır (Ap ve Wong, 2001: 551). Turist rehberleri, yalnızca ilginç bilgiler ve eğlenceli bir deneyim sağlamak için değil aynı zamanda destinasyonlarla alakalı fiziksel ve kültürel bir aşinalık sağlamak için varış yerinin "kapı bekçileri" olarak da hareket etmektedirler. Rehberler, turistlere ziyaret noktalarında neleri görmeleri veya neleri görmemeleri gerektiğini belirtmekte ve bunları yaparken çeşitli rolleri kullanarak önerilerde bulunmaktadırlar (Nelson, 2003: 114).

Esasen rol kavramının tanımı, kişiden kişiye, duruma ve zamana göre değişiklik gösterebilmektedir. Bazı araştırmacılara göre rol, belirli bir konumda olan ya da bu konumda görevlendirilmiş olan kişiden beklenen bir davranış şeklinde tanımlanmaktadır (Aslan, 2008: 173; Özkan, 2008: 4; Şahin, 2009: 27). Rol kavramı, genel olarak kişilerin hali hazırdaki davranışlar bütünü şeklinde ifade edilmektedir. Ancak kökeninde sosyoloji biliminin kapsadığı alanların içinde incelenmiş bir terim durumundadır. Bununla birlikte her ne kadar sosyolojiyle bağdaştırılsa da antropoloji ve sosyal psikoloji gibi hem sosyolojinin alt dalları hem de sosyolojiyle ilişkili yakın dalların da esas kavramlarından biridir (Birkök, 2004: 1; Özkan, 2008: 4). Turist rehberi açısından rol kavramının, bir misafirin beklenti, istek ve ihtiyaçları üzerinden değiştiğini ve şekillendiğini belirtmek gerekmektedir (Temizkan, 2005: 43). Ancak turist rehberlerinin yalnızca misafirlere yönelik değil aynı zamanda yerel halk ve topluma, temsil ettikleri ülkeye, çalıştıkları acentalara, gidilen destinasyonun kültürüne, doğaya ve çevreye, sanata ve bilhassa kendisine yönelik birçok sorumluluğu ve sayısız rolü de bulunmaktadır (Tetik Dinç, 2019: 184).

\section{Turist Rehberlerinin Yorumlayıcı Rolü}

Turist rehberlerinin yorumlayıcı rolü, bir destinasyona giden ziyaretçilerin gittikleri yeri daha iyi anlamasında ve o kültürü kavramasında büyük bir öneme sahiptir (Köroğlu, 2013: 107). 
Yorumlayıcı rol, kültürler arası bir bağlantı unsuru olarak görülmektedir. Gidilen destinasyondaki anlamlandırılamayan unsurları ve bilinmeyenleri yerel kültürle anlamlı kılan ve bu anlamı turistlerin anlayacağı bir dille ifade eden rollerinden biri yorumlayıcı roldür. Turist rehberleri, anlaşılamayan kültürlerden anlaşılabilir bir kültüre geçişi sağlamak amacıyla bir sanat eserini, yeri veya olayı, canlı ve merak uyandıracak bir şekilde yorumlama unsurunu kullanmaktadır (Rabotic, 2010: 3). Bilginin tek başına verilmesinden ziyade yorumlanarak ziyaretçilere aktarılması, turist rehberinin en önemli iletişimsel görevi olarak görülmektedir (McDonnell, 2001: 2). Turist rehberlerinin en önemli iletişim rolleri görsel ve kültürel manzarayı ziyaretçiler için yorumlamaktır. Rehberler, ziyaretçilerin tur deneyimini iletişim problemleri, vurdumduymazlık veya otoritesini uygun olmayan zamanda sağlama çabası nedeniyle tehlikeye atabilmektedir. Bir rehber için gelen ziyaretçiyi destinasyondaki halktan izole etmek bir çözüm olabilir. Fakat tura farklı sebeplerle gelen, farklı deneyimler arayışında olan turistler bu durumdan pek hoşnut olmayabilirler (Avcıkurt, 2015: 115). Çevresel etmenlerde turist rehberinin yorum yapabilmesi, ziyaretçi memnuniyetini teşvik ederek ve destinasyonların doğal ve kültürel kaynaklarının daha iyi anlaşılmasını sağlayarak sürdürebilir turizmin amaçlarına ulaşmasına yardımcı olmaktadır (Moscardo, 2003: 115). Turist rehberinin etkili yorumu ayn zamanda ziyaret edilen alanın önemini ileten, çevre ve yerel kültür hakkında daha fazla farkındalık yaratan, ziyaretçilere uygun davranışları ileten, sosyal ve biyolojik çevreyi olumsuz yönde etkileyen davranışlar hakkında uyarılarda bulunan, bu çevreler hakkında kaliteli bilgi sunan bir eğitim aracı olmaktadır (Poudel ve Nyaupane, 2013: 660).

Rehberi "yorumlayıcı rehber" olarak ilk defa çalışmalarında kullanan Weiler ve Ham (2001), ekoturizmin başarılı bir şekilde icra edilmesinde bu rolün önemli bir yere sahip olduğunu belirtmektedirler. Bu anlayış sadece ekoturizm için değil kitlesel ve diğer turizm türleri için de gelişimin sürdürebilir şekilde gerçekleşmesinde yorumlamanın etkinliğini göstermektedir ( $\mathrm{Hu}$ ve Wall, 2012: 83; Çapar ve Yenipınar, 2017: 406). Randall ve Rollins (2009: 362) çalışmalarında turist rehberinin yorumlama rollerinin ziyaretçilere doğal ve kültürel kaynaklara olan farkındalık konusunda eğitici nitelikte olduğunu ve bu sayede doğal çevrenin korunmasıyla birlikte uzun vadede fayda oluşturduğunu belirtmektedirler. Ap ve Wong'a (2001: 553) göre turist rehberlerinin yorumlayıcı rolleri ziyaretçilerin destinasyon kültür deneyimini ve anlayışını arttırmada hayati bir rol oynamaktadır. Turist rehberi iletişim becerileri sayesinde bir destinasyonun cazibe merkezlerini yorumlayarak, turistlerin ziyaretlerini basit bir turdan deneyime dönüştürebilmektedir.

Tüm bunlar ışığında turist rehberi sadece bilgi sağlamakla kalmamakta, aynı zamanda turistleri destinasyon deneyimlerinde merkezi bir yerde tutarak onları eğlendirmektedir. Turist rehberinin yorumlayıcı rolünün turist memnuniyetine etkisi oldukça açıktır. Yorumlayıcı rolün turist memnuniyeti ile birlikte, destinasyon sadakati veya destinasyon bağlllı̆̆ 1 arasındaki ilişkiye de etkisi mümkün görülmektedir (Yamada, 2011: 142; Chen ve Chen, 2010: 30).

\section{Destinasyon Sadakati}

Tekeli'ye (2001: 57) göre destinasyon bir kişinin zihninde algıladığı somut olan bir yerdir. Destinasyon, yapılan seyahat sonucu varış noktası olan nihai yer anlamına da gelmektedir (Anand, 1997: 40). Aynı zamanda destinasyon, birçok boyutu olan hizmet ve turizm imkanlarının tamamıdır (Hu ve Ritchie, 1993: 26). Destinasyon ifadesini algısal bir kavram olarak kabul eden tüketiciler, kültürel birikimlerinden, ziyaret etme amacından, güzergahtan, geçmiş deneyimleri ve eğitim seviyesinden dolayı öznel şekilde de yorumlayabilmektedirler (Sarı ve Kozak, 2005: 254; Buhalis, 2000: 97). 
Sadık olarak nitelendirilen müşterilerin değerli olduğu düşüncesi işletmeleri, kendilerine tekrar gelecek müşterilere yönelik teşvikler ve fiyat politikası gibi ucuz olmayan sadakat yöntemlerini gerçekleştirmeye yönlendirmektedir. Bu yöntemler kumarhane, restoran, eğlence ve tema park1, otel, havayolu işletmesi ve kruvaziyer gemileri gibi işletmelerde yaygın olarak kullanılmaktadır (Croes, Shani ve Walls, 2010: 120). Bu tür sadakat yöntemleri, destinasyonu pazarlayan kişilerin veya kurumların dikkatini de çekmektedir. İster kendiliğinden ister bir program içerisinde olsun, bu yönelimin kullanımı artarak devam etmektedir. Bununla birlikte destinasyon sadakati sağlamak için çeşitli yöntemler ve stratejiler kurgulanmakta ve uygulanmaktadır (Ağcakaya, 2019: 98). Çeşitli kaynaklarda destinasyon sadakati ve destinasyon tatmini aynı şekilde ve birbirlerinin yerlerine kullanılmış olarak görülebilmektedir. Fakat sadakat, ziyaretçilerin başkalarına yönelik destinasyon hakkındaki olumlu ifadeleri kapsamakla birlikte destinasyona geri gelme isteğini de ölçmeyi içerisine alabilmektedir. Tatmin ise ziyaretçilerin destinasyon hakkındaki beklentileri ne seviyede karşıladığını göstermektedir (McDowall, 2010: 27).

Çeşitli çekicilik unsurlarına sahip olan destinasyonlar, ziyaretçilerin tekrar ziyaret etme niyetine güven duyarak turizm faaliyetlerini devam ettirmektedirler (Oppermann, 2000: 80). Bundan dolayı ziyaretçilerin destinasyonlardan aldıkları memnuniyet ile buralara yönelik sadakat eğilimleri arasında güçlü bir ilişki vardır (Martin ve Collado ve del Bosque, 2013: 328). Destinasyona karşı gelişen sadakat eğilimleri, gidilen yerlere karşı oluşan olumlu geri dönüşlerin bir göstergesi niteliğindedir (Oppermann, 2000: 78). Turizm çerçevesinde sadakat, bir turistin daha önce ziyaret ettiği bir yeri yeniden ziyaret etmesi ve bununla birlikte gittiği yer ile ilgili fikir ve görüşlerini başkalarına aktarması ve tavsiyelerde bulunmasıdır (Yılmaz, 2011: 20). Başka bir ifadeyle, turistin destinasyon ziyareti süresince aldığı hizmet kalitesi ve destinasyonun ilgi çekici özellikleri gibi olumlu geri bildirimler, ziyaretçileri motive edip memnuniyet oluşturmaktadır. $\mathrm{Bu}$ memnuniyet sonucunda, ziyaretçiler deneyimlerini arkadaşları, ailesi veya dostları gibi çevreleriyle paylaşıp destinasyonu tekrar ziyaret etmesiyle, destinasyona sadakat göstermiş olmaktadırlar (Kılıç, 2011: 241). Firmalar açısından bakıldığında müşteri sadakati istenen ve aynı zamanda beklenen bir durum olmasıyla beraber, destinasyonların ekonomik avantajları açısından aynı şekilde istek ve beklentileri olabilmektedir (Ağcakaya, 2019: 43-44). Anastassova'ya (2004: 415) göre bir turist, destinasyonlar için yalnızca ekonomik bir figür değildir. Aynı zamanda sadık turistler, bir destinasyonun gizli savunucusu olarak görülmekle beraber destinasyonlar bu sayede daha avantajlı olarak gösterilmektedir.

Destinasyon sadakati üzerine yapılan araştırmaların çoğu, turizmin bünyesinde kendine özgü özellikleri olsa da hizmet ve ürün sadakati alanyazınına bağlı bir çerçeveye dayanmaktadır (Oppermann, 2000: 80). Destinasyon sadakatinin potansiyel belirleyicileri, ziyaretin sonunda oluşmuş olan tatmin, turistlerin sosyo-demografik özellikleri, destinasyona aşinalık ve turist güdüleridir (Kastenholz, Carneiro ve Eusebio, 2006: 240). Tüm bunlar 1şı̆̆ında ziyaretçilerin destinasyonlara sadık olma ihtimalleri ve sadakatin ne seviyede olması gerektiğinin altında yatan sebepleri hala tartışma konusudur. Bu görüş turistlerin belirgin düzeyde sadık olma eğilimlerinin olduğunu iddia eden düşünceye dayanmaktadır (McKercher ve Guillet, 2010: 3).

\section{İlgili Araştırmalar}

İlgili alanyazın incelendiğinde turist rehberlerinin rolleri arasında yer alan "yorumlayıcı rol" kavramının destinasyon sadakati, sürdürülebilir destinasyon yönetimi, iş yaşamındaki rolleri, otantik turizmdeki rolü ve jeoturizm gibi değişkenlerle ilişkilendirilen çalışmalar olduğu görülmektedir (Weiler ve Ham, 2001; Reisinger ve Steiner, 2006; Touloupa, 2010; Weiler ve Ham, 2010; Hu ve Wall, 2012; Köroğlu, 2013; Kuo vd., 2016; Poudel ve Nyaupane, 2015; Tetik, 2016; Köroğlu vd., 2018). 
Bununla birlikte destinasyon sadakati kavramına bakıldığında ilgili alanyazın incelemesiyle birlikte birçok çalışmanın bulunduğu görülmektedir (Oppermann, 2000; Duman ve Öztürk, 2005; Yoon ve Uysal, 2005; Kılıç, 2011; Yılmaz, 2011; Benli, 2014; Gürün, 2014; Yılmazdoğan, 2017; Şengül ve Türkay, 2018; Ağcakaya, 2019).

\section{Yorumlayıcı Rol ile İlgili Yapılan Araştırmalar}

İlgili alanyazında yorumlayıcı rolün destinasyon sadakati üzerine etkileri, turist rehberlerinin iş yaşamındaki rolleriyle alakalı yorumlayıcı rolün önemini belirtilen çalışmalar, sürdürülebilir destinasyon yönetiminde rehberlerin yorumlayıcı rollerinin etkileri gibi çeşitli değişkenler üzerine yapılan çalışmalar bulunmaktadır.

Kuo ve diğerleri (2016) yapmış oldukları çalışmada, Tayvan'ın Kimmer Savaş Alanı turizminde turist rehberlerinin yorumlayıcı rolünün ve turist memnuniyetinin destinasyona tekrar ziyareti yani sadakatinin üzerine etkisini, algılanan akış ve algılanan eğlenilebilirlik ile ilişkilendirmektedir. Yazarların daha önce Kimmer Savaş Alanlarını ziyaret eden 482 kişiye yaptıkları anket sonucunda, turist rehberlerinin yorum gücünün turistler üzerinde destinasyona olan bağlılığını güçlendirdiği sonucuna varılmaktadır. Fakat tek başına yapılan kaliteli bir yorumlamanın, turistlerin yeniden ziyaret niyetini garanti etmediği belirtilmektedir. Bu niyetleri yaratmak için öncelikle turist memnuniyetinin sağlanması gerektiği vurgulanmaktadır.

Köroğlu (2013) çalışmasında, turist rehberlerinin iş yaşamındaki rolleri üzerine kavramsal bir değerlendirme yapmaktadır. Bu konuyla alakalı literatürden örnekler verilerek en çok kullanılan rehber rolleri ve nedenleri belirtilmektedir. Çalışmada özellikle Black ve Weiler'in (2005) oluşturdukları tablodan yola çıkarak, rehberlerin anahtar rollerinin yorumlayıcı rolü olduğunu belirtilmektedir.

Poudel ve Nyaupane'nin (2015) sürdürülebilir destinasyon yönetiminde turist rehberlerinin yorumlayıcı rolü üzerine yaptıkları çalışmada, rehberli ve rehbersiz gezen turistler arasında bir karşılaştırma yapılmaktadır. Veri toplama aşamasında sistematik rastgele örnekleme yöntemi kullanılan çalışmada, Annapurna Koruma Alanını ziyaret eden yerli ve yabancı turistler, araştırmacıların geliştirdiği ankete cevap vermektedir. Çalışma sonucunda rehberli tur ziyaretçilerinin çevreye karşı sorumlu davranışlara katılımı, rehberi olmayan tur ziyaretçilerinin katılımı ile hemen hemen aynı bulunduğu görülmektedir.

Reisinger ve Steiner'in (2006) turist rehberlerinin otantik turizmdeki rolleri arasında yer alan yorumlayıcı rollerini yeniden kavramsallaştırmayı amaçlayan bir çalışma yaptıkları görülmektedir. Çalışma Martin Heidegger'in felsefesine dayandırılmaktadır. Heidegger'in yorumlayıcı tanımları, turist rehberleriyle ilişkilendirilmektedir. Çalışmada turist rehberlerinin basit bir yol göstericiden ziyade, yorumlayarak bir objeyi veya yeri daha anlamlı kılabileceği sonucuna varılmaktadır.

Tetik'in (2016) çalışmasında turist rehberlerinin jeoturizmde yorumlama rolünün önemine vurgu yapılmaktadır. İlgili literatür kapsamlı bir şekilde gözden geçirilerek, turist rehberlerinin jeoturizmdeki yorumlama rolünün önemi için bir çerçeve çizilmektedir. Çalışmaya göre başarılı bir yorumlama için jeotur rehberlerinin izlemesi gereken bir sürece vurgu yapılmaktadır. Bununla birlikte çalışma jeotur rehberlerinin başarısı için bir yorumlama süreci sunmaktadır. Sunulan süreç dikkatlice ve tamamen uygulandığında, turistlerin memnuniyetine, jeotur rehberlerinin kalitesine ve turizm işletmelerinin imajına katkıda bulunabileceği sonucuna varılmaktadır. 
Touloupa'nın (2010) yapmış olduğu çalışmada, turist rehberlerinin küresel düzeyde bir kimliği kültürel miras yorumuyla nasıl ifade ettiklerine vurgu yapılmaktadır. Yunanistan'da tartışılan bir konu olan turist rehberlerinin bazı konularda yorum yoluyla yanlış bilgiler verdiğine inanıldığı belirtilmektedir. Çalışmanın sonucunda Yunan turist rehberlerinin uluslararası konularda yanlış anlaşılmaları ortadan kaldırmak amacıyla farklı unsurları yerel dille ifade ettiği söylenmektedir.

Weiler ve Ham (2001) çalışmalarında turist rehberi ve yorumlama ifadelerini bir arada kullanarak rehberlerin yorumlama rolünün gücüne vurgu yapmaktadır. Çalışmada turist rehberlerinin yorumlama rolünün ekoturlarda neden vazgeçilemez ve kritik olduğu ifade edilmektedir. Çalışmanın sonunda turist rehberlerinin, korunması gereken doğayı yorumlama rolü vasıtasıyla daha anlamlı kılabileceği, koruyabileceği ve ekoturistlerin deneyimlerinin kalitesini arttırabileceği tespit edilmiştir.

Köroğlu ve diğerleri (2018) çalışmalarında turist rehberlerinin yorumlayıcı rollerine yönelik algıların betimsel analiz yöntemiyle belirlenmesi amaçlandığına vurgu yapılmaktadır. Çalışmanın amacına uygun olarak bir soru formu oluşturulmuş ve 43 turist rehberine sorular sorulmaktadır. Turist rehberlerinin en fazla "zenginleştirme" ifadesinin kullanıldığ 1 belirtilmektedir. Bununla birlikte bilgiyi düz ve sade vermektense çeşitli jest ve mimiklerle mizahi şekilde hikâyeleştirerek turistlere vermenin yorumlama gücüne katkısı ifade edilmektedir.

$\mathrm{Hu}$ ve Wall (2012) çalışmalarında turist rehberleri ve sürdürülebilir kalkınma arasındaki bağlantıları incelemekte ve yorumlayıcı rollerine yönelik bir çerçeve önermektedirler. Davranışsal, yönlendirici ve eğitici olmak üzere 3 çeşit yorumlayıcı bilgi olduğuna değinmekle beraber yorumlamanın yalnızca turist rehberlerinin sorumluluklarından biri değil, aynı zamanda sürdürülebilir kalkınmayı kolay hale getirmek için turist rehberlerinin yapması gereken bütün faaliyetlerin temelinde olduğuna vurgu yapmaktadırlar.

\section{Destinasyon Sadakati ile İlgili Yapılan Araştırmalar}

Ağcakaya (2019), motivasyon faktörlerinin destinasyon sadakati üzerine etkisini belirlemeye yönelik bir yüksek lisans tez çalışması yapmıştır. Araştırma, kış turizmi kapsamında ErzurumPalandöken'i ziyaret eden 471 yerli turist üzerinde yapılan bir anket çalışmasıyla gerçekleştirilmiştir. Araştırmanın sonucunda yerli turistlerin, destinasyona sadakati üzerinde destinasyon memnuniyeti ve imajı ile birlikte motivasyon faktörlerinin de etkili olduğu belirtilmektedir. Bu durum, araştırmaya katılan turistlerin çeşitli özelliklerine göre değişmekte olduğu vurgulanmaktadır.

Benli (2014), Mersin'i ziyaret eden yerli turistler üzerinde yapmış olduğu, yöresel lezzet deneyiminin destinasyon imajı ve destinasyon sadakati üzerine etkisine yönelik çalışmasında katılımcıların, yerel yiyecek deneyimlerini 4 (dört) faktörde algıladıklarını ifade etmektedir. Tüm bunlar 1şığında destinasyon imajı sayesinde, ziyaretçilerin yöresel lezzet deneyimlerinin destinasyon sadakati üzerindeki etkisinin arttığını belirtilmektedir.

Duman ve Öztürk (2005), Mersin Kızkalesi destinasyonuna yönelik yerli turistlerin tekrar ziyaretlerine, bir diğer ifadeyle destinasyon sadakatleri niyetine ve ilgili algılamaları üzerine çalışma yapmışlardır. 231 yerli turistle yapılan araştırma sonucunda müşteri memnuniyetini etkileyen 2 (iki) faktör olduğu tespit edilmiştir. Bunlar konaklama yeriyle birlikte sunulan yiyecek içecek hizmetleri ve misafirperverlik olarak belirtilmektedir. Bununla birlikte destinasyon sadakatleri açısından bu faktörlere ek olarak hizmetlerin ve aktivitelerin önemli bir unsur oldukları sonucuna varılmaktadır. 
Niğde Çiftehan Kaplıcaları için, termal turizm işletmelerine gelen turistlerin tatmin düzeylerinin destinasyon sadakati üzerin etkisini belirlemek amacıyla yapılan çalışmada Gürün (2014), Çiftehan Kaplıcalarını tekrar ziyaret etmek isteyen turistlerin en çok bu bölgenin havasının temiz olduğundan ve ikamet ettikleri bölgelere yakın olduğundan dolayı tekrar ziyaret etmek istedikleri sonucuna ulaşmıştır. Bununla birlikte kaplıcanın temiz ve hijyenik olması, içerisinde bulunan restoranların menü zenginliği, güvenliğine önem verilmesi, turistlerin bu destinasyona sadakat göstereceklerini belirtmelerindeki diğer faktörler olduğu belirtilmektedir.

Kılıç (2011) çalışmasında destinasyon ziyaretçilerinin sosyo-demografik özelliklerinin sadakat eğilimlerine etkisini belirlemek amacıyla bir turist grubuna anket çalışması yapmıştır. Araştırma sonunda ankete katılan turistlerin sadakat eğilimlerinin oldukça fazla olduğu belirtilmektedir. Ayrıca sosyo-demografik özellikleri açısından milliyet/ülke faktöründe ise anlamlı bir farklılık tespit edildiği görülmektedir.

Oppermam (2000) çalışmasında, başarılı şirketler için sadakatin önemli bir itici güç olduğuna dair yaygın bir görüş olmasına rağmen, turizm destinasyonu sadakatinin kendi dönemine kadar araştırılmadığını belirtmektedir. Çalışmasının amacının esasında destinasyon sadakatinin uygulanabilirliği ve kullanışlılığı olduğunu belirtmektedir. Destinasyon sadakati ile ilgili verilerin toplanmasının, işletmelerin veya destinasyonların iyi bir öngörme ve talep tahmini yapmasında önemli bir rol oynayacağına vurgu yapılmaktadır.

Şengül ve Türkay (2018) tarafından yapılan çalışmada, yöresel mutfak marka değer algısının destinasyon sadakati ve destinasyon farkındalığı üzerindeki etkisi vurgulanmaktadır. Araştırma, Bolu Mudurnu'da 550 yerli turiste yapılan anket ile gerçekleştirilmiştir. Yapılan anketlere göre yöresel mutfak marka değerinin, destinasyon sadakati ve farkındalığı üzerinde olumlu yönde bir etkiye sahip olduğu vurgulanmıştır. Bu sonuçlar, bölgedeki turizm işletmeleriyle ve destinasyon yöneticileriyle paylaşılmakla beraber çıan sonuca göre önerilerde bulunulduğu belirtilmektedir.

Yılmaz (2011) çalışmasında, destinasyon sadakatini etkileyen faktörlerin neler olduğunu Belek golf turizmi örneğiyle araştırmıştır. Belek'teki golf alanını ziyaret eden 1250 golf turistine anket uygulanmıştır. Bunların 900 tanesi kullanılabilmiştir. Araştırma sonucuna göre duygusal imajın destinasyon sadakatini etkileyen en önemli unsur olduğu görülmektedir. Bununla beraber golf sahasındaki hizmet kalitesinin ve golf odaklı seyahat güdüsünün de sadakati etkileyen diğer unsurlar arasında olduğu belirtilmektedir. Araştırmada golf turistlerinin gidecekleri golf alanını belirlerken televizyon, fuar ve internet gibi unsurları kullandığı ifade edilmektedir. Bu gibi iletişim araçlarının etkin kullanılması gerektiğinin altı özellikle çizilmektedir.

Yılmazdoğan (2017) çalışmasında, destinasyon aidiyetini ve öncüllerinin destinasyon sadakati üzerine etkisini araştırmıştır. Araştırma sonucunda destinasyon sadakati, aidiyet, destinasyon çekiciliği ve memnuniyet arasında olumlu yönlü ve anlamlı ilişkiler olduğu belirtilmektedir. Tüm bunlar 1şığında destinasyona karşı hissedilen aidiyetin, turistleri destinasyon sadakatine yönlendiren en önemli unsur olduğu ifade edilmektedir. Bunlar haricinde destinasyona duyulan memnuniyetin de turistlerin sadakat eğilimine etkisi olduğu görülmektedir.

Yoon ve Uysal (2005) yapmış oldukları çalışmada, motivasyon ve memnuniyetin destinasyon sadakati üzerindeki etkilerini incelemekte ve yapısal bir model oluşturmaktadır. Araştırma sonucunda destinasyon yöneticilerinin, destinasyon sadakatini arttırmak ve sürdürmek amacıyla, satın alma sonrası olumlu turist davranışı yaratmak için yüksek bir turist memnuniyet düzeyi oluşturmaları gerektiği belirtilmektedir.

Literatürü toplamak gerekirse hem yorumlayıcı rol hem destinasyon sadakati ile ilgili birçok araştırma bulunmaktadır. Bu araştırmalar incelendiğinde iki kavramın karşılaştırılması gereken araştırmaların yok denecek kadar az olduğu görülmektedir. Buradan hareketle rehberlerin 
yorumlayıcı rolünün turist destinasyon sadakatini üzerine etkisinin araştırılması önem arz etmektedir.

\section{YÖNTEM}

Çalışmanın amacı doğrultusunda turist rehberlerinin yorumlayıcı rollerinin destinasyon sadakati üzerine etkisinin incelendiği çalışmalardan hareket ederek hipotezler oluşturulmuş ve araştırmanın modeli belirlenmiştir. Bilimsel yöntemin kaynağını sınama kavramı oluşturmaktadır. Araştırmacı üzerinde çalıştı̆̆ probleme sebep oluşturan değişkenleri ilk önce ilgili literatürdeki değişkenler arasındaki ilişkileri dikkate alarak tahmin etmektedir. Ardından tahminlerini başkalarının kabul edebileceği "ortak ölçütlere" göre denemeye veya sınamaya çalışmaktadır. Bu durumdan hareketle hipotezler geliştirmektedir (Karasar, 2016: 98). Kuo ve diğerleri (2016) tarafından yapılan çalısmada turist rehberlerinin yorumlayıcı rolünün turistlerin destinasyon sadakatini etkilediği belirtilmektedir. Aynı zamanda yorumlayıcı rolünün turistlerin destinasyon sadakatini etkileyen faktörler arasında yer alan turist memnuniyeti üzerinde güçlü bir yeteneğe sahip olduğu sonucuna ulaşılmaktadır. Bu araştırma turizmin önemli paydaşlarından biri olan turist rehberlerinin yorumlayıcı rolünün destinasyon sadakatine etkisinin olup olmadığını belirlemek ve aynı zamanda turist memnuniyetinin destinasyon sadakatindeki aracılık rolünü incelemeyi amaçlamaktadır. Buradan hareketle Kuo ve diğerleri (2016) tarafından yapılmış olan araştırma sonuçları dikkate alınarak turist rehberlerinin yorumlayıcı rollerinin destinasyon sadakati üzerine etkisine ilişkin hipotezler şu şekilde belirlenmiştir:

H1: Turist rehberlerinin yorumlayııı rolü turist memnuniyetini etkilemektedir.

H2: Turist memnuniyeti turist destinasyon sadakatini etkilemektedir.

H3: Turist rehberlerinin yorumlayıc rolü turist destinasyon sadakatini etkilemektedir.

H4: Turist rehberlerinin yorumlayıcı rolü, turist memnuniyeti aracılığıyla turistlerin destinasyon sadakatini etkilemektedir.

Yukarıda belirtilen hipotezler göz önüne alınarak araştırma modeli oluşturulmuştur. Aşağıda yer alan Şekil 1'de araştırma modeline yer verilmiştir.

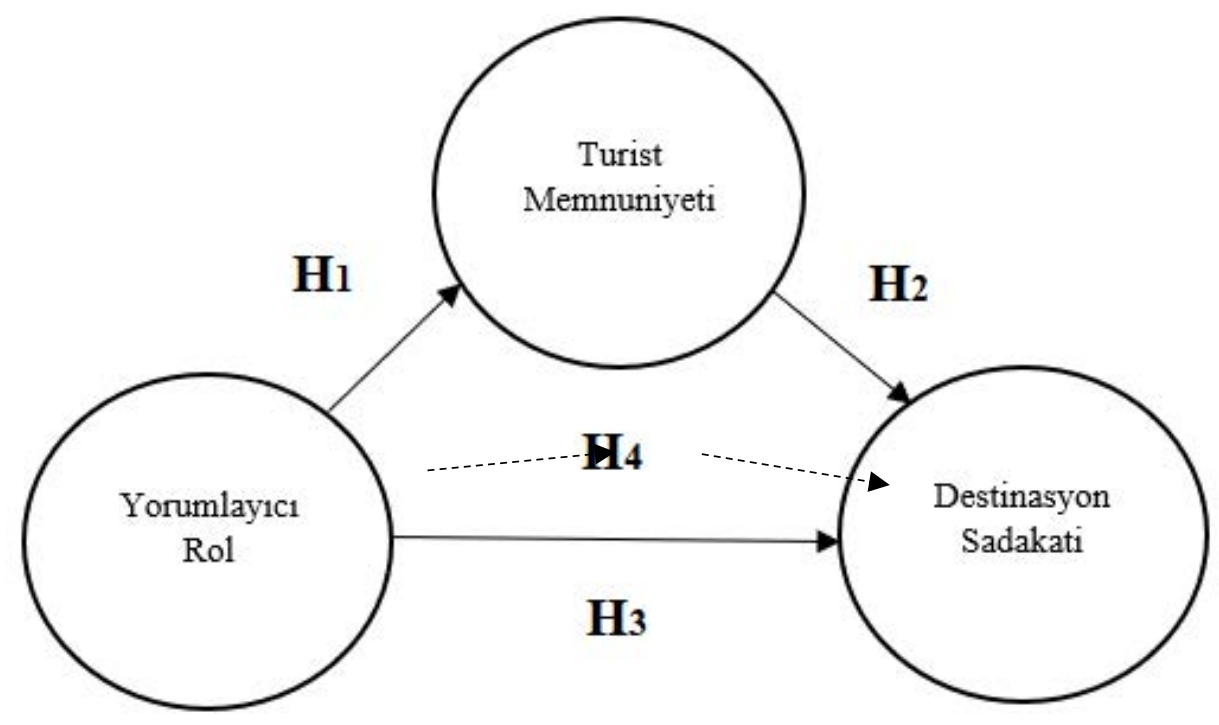

Şekil 1. Araştırma Modeli 


\section{Veri Toplama Aracı}

Bu çalışmada Çanakkale Savaşları Gelibolu Tarihi Alanı'nı Mayıs 2019-Şubat 2020 tarihleri arasında rehberli bir tura katılım sağlayarak ziyaret etmiş 393 katılımcıya ulaşılmıştır. Ancak katılımclardan elde edilen iki ankette yer alan veriler yetersiz ve anlamsız olması sebebiyle değerlendirmeye dahil edilmemiştir. Araştırma analizleri 391 anket formu üzerinden yürütülmüştür. Bu çalışmada öncelikle turist rehberlerinin yorumlayıcı rollerinin destinasyon sadakati üzerindeki etkisine yönelik alanyazın incelemesi yapılmıştır. Elde edilen kuramsal bilgiler ışığında Kuo ve diğerleri (2016) tarafından yapılmış olan çalışmadan yararlanarak anket formu oluşturulmuştur. Buradan hareketle likert ölçeği (1. Kesinlikle Katılmıyorum, 2. Katılmıyorum, 3. Kararsızım, 4. Katılıyorum, 5. Kesinlikle Katılıyorum) kullanılarak oluşturulan anket formunda katılımcılardan ifadelerinin cevaplanması istenmiştir. Anket formu iki bölümden oluşmaktadır. Oluşturulan formun ilk bölümünde cinsiyet, yaş, eğitim seviyesi, meslek ve medeni halden oluşan 5 soru bulunmaktadır. Ayrıca ziyaretçilerin Çanakkale Gelibolu Tarihi Alanı'nı daha önce ziyaret etme durumlarıyla ziyaret sıklıkları ve daha önce Çanakkale'ye yönelik rehberli bir tura katılma durumlarıyla beraber memnuniyetlerine yönelik 4 soru ile birlikte toplam 9 soru bulunmaktadır. Anket formunun ikinci bölümünde turist rehberlerinin yorumlayıcı rollerine, tura yönelik memnuniyetlerine ve bölgeye yönelik sadakat düzeylerine ilişkin ifadeler bulunmaktadır. Yorumlayıcı rollerine ilişkin ifadeleri Tilden (1957), Sharpe (1982), Regnier, Gross ve Zimmerman'ın (1992) çalışmalarından düzenlenerek, memnuniyetlerine yönelik ifadeleri Ryu, Han ve Kim'in (2008) çalışmalarından düzenlenerek, son olarak anket katılımcılarının bölgeye yönelik sadakat düzeylerine yönelik ifadeleri Yoon ve Uysal'ın (2005) çalışmalarından düzenlenerek Kuo ve diğerleri (2016) tarafından yeniden oluşturulmuştur. Anket formu 19'u rehberlerin yorumlayıcı rollerine, 4'ü ziyaretçi memnuniyetine ve 3'ü destinasyon sadakatine yönelik cevaplanması beklenen toplam 26 ifadeden oluşmaktadır.

\section{Evren ve Örneklem}

Turist rehberlerinin yorumlayıcı rolünün destinasyon sadakati üzerine etkisini ölçmek amacıyla araştırma evrenini Çanakkale Savaşları Gelibolu Tarihi Alanı'na bir rehberle ziyaret gerçekleştirmiş turistler oluşturmaktadır. Çanakkale Savaşları Gelibolu Tarihi Alan Başkanlığı'nın 2019 yılı faaliyet raporuna göre alanın toplam ziyaretçi sayısı bilinmemekle birlikte, alan içerisinde yer alan Çanakkale Destanı Tanıtım Merkezini (ÇDTM) kurulduğu yıl olan 2012'den itibaren 1.972.575 kişinin ziyaret ettiği belirtilmektedir (www.catab.ktb.gov.tr). Buradan hareketle Çanakkale Savaşları Gelibolu Tarihi Alanı'nı ziyaret eden kişi sayısı milyonları bulabilmektedir.

\section{BULGULAR}

Araştırmaya katılan anket katılımcılarına ait demografik özelliklerine ilişkin verilerin frekans analizi sonuçları Tablo 1'de görülmektedir. Tablo 1'de görüldüğü üzere elde edilen bulgular ışığında 391 katılımcının büyük çoğunluğunu kadın katılımcıların oluşturduğu görülmektedir. Bu bağlamda araştırmaya dahil olan anket katılımcılarının \%56,8'i kadın katılımcılardan, \%43,2'si erkek katılımcılardan oluşmaktadır. 
Katılımcların yaşlarına ilişkin bulgular incelendiğinde katılımcıların \%48,1'ini 19-28 yaş arası bireyler oluşturmaktadır. Diğer katılımcıların yaş değişkenlerine ilişkin oranlar incelendiğinde, \%20,7'si 29-38 yaş, \%11,5'i 49-58 yaş, \%10,2'si 39-48 yaş, \%5,1'i 18 yaş ve altı ve \%4,3'ü 59 yaş ve üstü şeklinde görülmektedir.

Katılımcıların eğitim durumlarına bakıldı̆̆ında \%65,7'sinin lisans düzeyinde, \%18,9'unun lise düzeyinde, $\% 7,2^{\prime}$ sinin lisansüstü düzeyinde, $\% 5,6^{\prime}$ sının ilköğretim düzeyinde ve $\% 2,6$ 'sının doktora düzeyinde eğitim aldığı görülmektedir.

Araştırmaya katılan kişilerin mesleki durumlarına ilişkin bulgulara bakıldığında ise \%32,5'inin ( $\mathrm{n}=127$ ) öğrenci, \%31,2'sinin özel sektör çalışanı, \%12,8' inin memur, \%11,8' inin emekli, \%7,2'sinin ev hanımı, \%3,1 işçi ve \%1,5'inin ise diğer ifadesinin oluşturduğu meslek gruplarından olduğu görülmektedir. Diğer meslek gruplarını kabin memuru, serbest muhasebeci ve herhangi bir işi olmayanların oluşturduğu görülmektedir.

Katılımcıların medeni hallerine ilişkin bulgular incelendiğinde araştırmaya katılan katılımcıların $\% 61,4^{\prime}$ ünün bekar ve \%38,6'sının ise evli olduğu görülmektedir.

Tablo 1. Katılımcıların Demografik Özelliklerine İlişkin Verilerin Frekans Analizi

\begin{tabular}{|c|c|c|c|}
\hline DEĞİŞKENLER & & $\mathrm{n}$ & $\%$ \\
\hline \multirow{3}{*}{ Cinsiyet } & Kadın & 222 & 56,8 \\
\hline & Erkek & 169 & 43,2 \\
\hline & Toplam & 391 & 100 \\
\hline \multirow{7}{*}{ Yaş } & 18 yaş ve altı & 20 & 5,1 \\
\hline & $19-28$ yaş & 188 & 48,1 \\
\hline & 29-38 yaş & 81 & 20,7 \\
\hline & $39-48$ yaş & 40 & 10,7 \\
\hline & $49-58$ yaş & 45 & 11,5 \\
\hline & 59 yaş ve üstü & 17 & 4,3 \\
\hline & Toplam & 391 & 100 \\
\hline \multirow{6}{*}{ Eğitim Seviyesi } & İlköğretim & 22 & 5,6 \\
\hline & Lise & 74 & 18,9 \\
\hline & Üniversite & 257 & 65,7 \\
\hline & Yüksek Lisans & 28 & 7,2 \\
\hline & Doktora & 10 & 2,6 \\
\hline & Toplam & 391 & 100 \\
\hline \multirow{8}{*}{ Meslek } & Memur & 50 & 12,8 \\
\hline & İşçi & 12 & 3,1 \\
\hline & Özel Sektör Çalışanı & 122 & 31,2 \\
\hline & Ev Hanımı & 28 & 7,2 \\
\hline & Emekli & 46 & 11,8 \\
\hline & Öğrenci & 127 & 32,5 \\
\hline & Diğer & 6 & 1,5 \\
\hline & Toplam & 391 & 100 \\
\hline \multirow{3}{*}{ Medeni Hal } & Evli & 151 & 38,6 \\
\hline & Bekar & 240 & 61,4 \\
\hline & Toplam & 391 & 100 \\
\hline
\end{tabular}


Anket katılımcılarına Çanakkale Savaşları Gelibolu Tarihi Alanı'nı daha önce ziyaret edip etmediği sorulduğunda \%61,4'ünün daha önce ziyaret gerçekleştirdiği ( $n=240), \% 38,6^{\prime}$ sının ise daha önce ziyaret gerçekleştirmeyip ilk kez ziyaret ettikleri tespit edilmiştir $(n=151)$. Çanakkale Savaşları Gelibolu Tarihi Alanı'nı daha önce ziyaret gerçekleştirmiş anket katılımcıların ziyaret sıklığının \%59,6'lık oranını daha önce iki kez ziyaret eden katılımcılardan olduğu görülmektedir $(n=143)$. Daha önce dört kez ve üzeri ziyaret gerçekleştiren katılımcıların \%20,4'ünü $(n=49)$ ve üç kez ziyaret gerçekleştirenler ise \%20'sini oluşturduğu görülmektedir $(n=48)$.

Katılımcılara daha önce Çanakkale'ye yönelik rehberli bir tura katılıp katılmadığı sorulduğunda $\% 51,9^{\prime}$ unun daha önce rehberli bir tura katıldığ $1(n=203), \% 48,1$ 'inin ise daha önce rehberli bir tura katılmadığ katılanlara memnun kalıp kalmadıkları sorulduğunda \%89,7'sinin memnun kaldığı $(n=182)$, $\% 10,3$ 'ünin ise memnun kalmadığı tespit edilmiştir ( $\mathrm{n}=21)$.

Tablo 2' de katılımcıların ziyaret durumları ve sıklıklarıyla beraber memnuniyetleri ile ilgili verilen frekans analizi sonuçları görülmektedir.

Tablo 2. Katılımcıların Ziyaret Durumları, Sıklıkları ve Memnuniyetleriyle İlgili Verilerin Frekans Analizi

\begin{tabular}{|l|l|c|c|}
\hline \multicolumn{1}{|c|}{ DEĞİŞKENLER } & & $\mathbf{n}$ & $\mathbf{\%}$ \\
\hline \multirow{3}{*}{$\begin{array}{l}\text { Çanakkale Savaşları Gelibolu Tarihi } \\
\text { Alanı'nın Daha Önce Ziyaret Edilme } \\
\text { Durumu }\end{array}$} & Evet & 240 & 61,4 \\
\cline { 2 - 4 } & Hayır & 151 & 38,6 \\
\cline { 2 - 4 } & Toplam & $\mathbf{3 9 1}$ & $\mathbf{1 0 0}$ \\
\hline \multirow{4}{*}{ Ziyaret Sıklı̆̆ı } & $2 \mathrm{kez}$ & 143 & 59,6 \\
\cline { 2 - 4 } & $3 \mathrm{kez}$ & 48 & 20 \\
\cline { 2 - 4 } & 4 kez ve üzeri & 49 & 20,4 \\
\cline { 2 - 4 } & Toplam & $\mathbf{2 4 0}$ & $\mathbf{1 0 0}$ \\
\hline \multirow{3}{*}{$\begin{array}{l}\text { Daha Önce Çanakkale'ye Yönelik Rehberli } \\
\text { Bir Tura Katılma Durumu }\end{array}$} & Evet & 203 & 51,9 \\
\cline { 2 - 4 } & Hayır & 188 & 48,1 \\
\cline { 2 - 4 } & Toplam & $\mathbf{3 9 1}$ & $\mathbf{1 0 0}$ \\
\hline \multirow{3}{*}{ Rehberli Turdan Memnun Olma Durumu } & Evet & $\mathbf{2 1}$ & 89,7 \\
\cline { 2 - 4 } & Hayır & $\mathbf{2 0 3}$ & $\mathbf{1 0 0}$ \\
\cline { 2 - 4 } & Toplam & \\
\hline
\end{tabular}

Tablo 3'te aritmetik ortalama, standart sapma ve Cronbach Alfa değerleri verilmektedir. Araştırmanın amacı kapsamında anket formları içerisinde yer alan ifadelere yönelik yorumlayıcı rol, memnuniyet ve sadakat ölçeklerine ilişkin güvenilirlik analiz yapılmış ve sonuçlar yorumlanmıştır. Ölçeklerin güvenilirliği Cronbach Alfa değeri hesaplanarak sağlanmıştır. Güvenilirlik analizi ölçekler içerisindeki ifadelerin iç tutarlılığını ölçmekle beraber aynı zamanda bu ifadeler arasındaki ilişkiye yönelik bilgi vermektedir. Cronbach Alfa değeri 0,70 ve üzerinde olan ölçeklerin bir tutarlılığa sahip olduğu ve güvenilir olduğu sonucuna varmak mümkündür (Bayram, 2004: 128). Yorumlayıcı rol ölçeğine ait 19 ifadenin güvenilirlik analizi sonucunda Cronbach Alfa değeri 0,96 olarak elde edilmiştir. Bu değerin ise tutarlı ve güvenilir olduğu görülmektedir. 
Tablo 3. Yorumlayıcı Rol Ölçeğinin Standart Sapma, Aritmetik Ortalama ve Cronbach's Alpha Değerleri

\begin{tabular}{|c|c|c|c|c|}
\hline Faktör & İfadeler & $\bar{x}$ & SD & $\begin{array}{c}\text { Cronbach's } \\
\text { Alpha }\end{array}$ \\
\hline \multirow{19}{*}{ 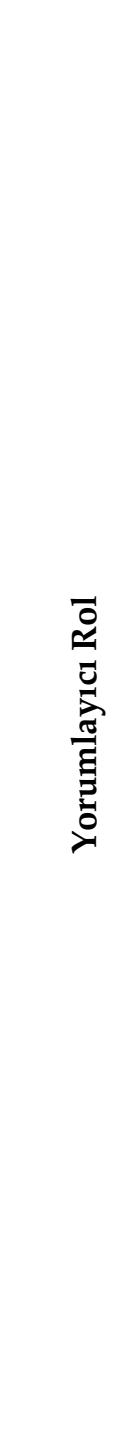 } & $\begin{array}{l}\text { Rehberin yaptığı yorumlardan bilgi } \\
\text { aldım. }\end{array}$ & 4,47 & 0,935 & \multirow{20}{*}{0,96} \\
\hline & $\begin{array}{l}\text { Rehberin tarihi alanla ilgili } \\
\text { yorumlarının içeriği zengindi. }\end{array}$ & 4,44 & 0,980 & \\
\hline & $\begin{array}{l}\text { Rehberin yorumları bu tarihi alan için } \\
\text { beni heyecanlandırdı. }\end{array}$ & 4,37 & 0,986 & \\
\hline & Rehberin yorumları hoştu. & 4,38 & 0,969 & \\
\hline & $\begin{array}{l}\text { Rehberin yorumları sayesinde savaş } \\
\text { alanı hakkında daha iyi bilgiye sahibim. }\end{array}$ & 4,40 & 0,987 & \\
\hline & Rehber akıcı şekilde yorumlar yaptı. & 4,45 & 0,929 & \\
\hline & Rehberin yorumları canlıydı. & 4,40 & 0,961 & \\
\hline & Rehberin yorumları açık ve anlaşılırdı. & 4,44 & 0,928 & \\
\hline & $\begin{array}{l}\text { Rehberin yorumları beni rahat ve keyifli } \\
\text { hissettirdi. }\end{array}$ & 4,33 & 0,982 & \\
\hline & Rehberin yorumları düz ve sıkıcıydı.* & 4,07 & 1,253 & \\
\hline & Rehber turistlerle iyi iletişim kurdu. & 4,29 & 0,977 & \\
\hline & $\begin{array}{l}\text { Rehber rahat bir yorumlama ortamı } \\
\text { sağladı. }\end{array}$ & 4,27 & 0,977 & \\
\hline & $\begin{array}{l}\text { Rehber yerel bilgileri anlamamıza } \\
\text { yardımcı oldu. }\end{array}$ & 4,39 & 0,932 & \\
\hline & $\begin{array}{l}\text { Rehber tutku ve ilgiyi yorumlama } \\
\text { yoluyla gösterdi. }\end{array}$ & 4,28 & 0,971 & \\
\hline & Rehberin yorumlama süresi uygundu. & 4,27 & 0,985 & \\
\hline & $\begin{array}{l}\text { Rehber, anlatımdan önce çalışmış ve } \\
\text { pratik yapmıştı. }\end{array}$ & 4,43 & 0,952 & \\
\hline & $\begin{array}{l}\text { Rehber yorumlarının içeriğiyle konu } \\
\text { hakkında artık bağlantı kurabilirim. }\end{array}$ & 4,59 & 0,740 & \\
\hline & $\begin{array}{l}\text { Rehber, farklı ziyaretçiler için farklı } \\
\text { yorum içeriği sağladı. }\end{array}$ & 4,47 & 0,793 & \\
\hline & Rehberin yorumları ilgi çekiciydi. & 4,59 & 0,787 & \\
\hline & TOPLAM & 4,39 & 0,948 & \\
\hline
\end{tabular}

(*) Iffade ters kodlanmıştır.

Yorumlayıcı rol ölçeğinin aritmetik ortalama ve standart sapma değerleri göz önünde bulundurulduğunda "Rehberin yorumları ilgi çekiciydi" ifadesi ve "Rehber yorumlarmın içeriğiyle konu hakkında artık bağlantı kurabilirim" ifadesi 4,59 ortalama ile en yüksek ortalamaya sahip ifadeler olarak görülmektedir. Bu ifadelere bakarak katılımcıların rehberlerin yaptığı yorumlarla birlikte Çanakkale Savaşları Gelibolu Tarihi Alanına ilişkin bilgilerinin rehberin yorumları sayesinde daha yüksek olduğu görülmektedir. Bununla birlikte ortalama değerleri içerisinde en düşük değere sahip ifade ise "Rehberin yorumları düz ve sıkıcıydı" ifadesi olduğu görülmektedir. Bu ifadenin 4,07 ortalamaya sahip olduğu saptanmıştır. Tablo 4 'te turist memnuniyeti ölçeğine ilişkin aritmetik ortalama ve standart sapma değerleri verilmektedir. Araştırmada yer alan memnuniyet ölçeğine ilişkin güvenilirlik analiz sonuçları verilmektedir. 
Memnuniyet ölçeğinde yer alan 4 ifadenin Cronbach Alfa değeri 0,96 olduğu görülmektedir. Bu değer $0,70^{\prime}$ den büyük olmasından dolayı tutarlı ve güvenilir olduğu söylenebilmektedir.

Tablo 4. Turist Memnuniyeti Ölçeğinin Aritmetik Ortalama, Standart Sapma ve Cronbach's Alpha Değerleri

\begin{tabular}{|c|c|c|c|c|}
\hline Faktör & İfadeler & $\bar{x}$ & SD & $\begin{array}{l}\text { Cronbach's } \\
\text { Alpha }\end{array}$ \\
\hline \multirow{4}{*}{ F } & $\begin{array}{l}\text { Bu turun tüm atmosferinden memnun } \\
\text { kaldım. }\end{array}$ & 4,37 & 0,968 & \multirow{5}{*}{0,96} \\
\hline & Turu aldığım için memnunum. & 4,42 & 0,951 & \\
\hline & Tur sırasında hoş duygular hissettim. & 4,46 & 0,959 & \\
\hline & Bu turu gerçekten beğendim. & 4,40 & 1,003 & \\
\hline \multicolumn{2}{|r|}{ TOPLAM } & 4,41 & 0,970 & \\
\hline
\end{tabular}

Turist memnuniyeti ölçeğinin aritmetik ortalama ve standart sapma değerleri incelendiğinde "Tur sırasında hoş duygular hissettim" ifadesi 4,46 oranı ile en yüksek değer olarak görülmektedir. "Bu turun tüm atmosferinden memnun kaldım" ifadesi ise 4,37 oranı ile en düşük değere sahip ifadedir. Tablo 5'te destinasyon sadakati ölçeğine ilişkin standart sapma, ortalama ve Cronbach Alfa değerleri verilmektedir.

Tablo 5. Destinasyon Sadakati Ölçeğinin Aritmetik Ortalama ve Standart Sapma Değerleri

\begin{tabular}{|c|c|c|c|c|}
\hline Faktör & İfadeler & $\overline{x^{-}}$ & SD & $\begin{array}{l}\text { Cronbach's } \\
\text { Alpha }\end{array}$ \\
\hline \multirow{3}{*}{ 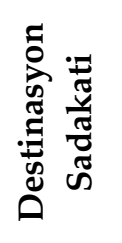 } & Bu turu insanlara tavsiye edeceğim. & 4,44 & 0,929 & \multirow{4}{*}{0,77} \\
\hline & $\begin{array}{l}\text { Çanakkale Savaşları Gelibolu Tarihi } \\
\text { Alanı'nı tekrar ziyaret edeceğim. }\end{array}$ & 4,30 & 0,962 & \\
\hline & $\begin{array}{l}\text { Burayı tekrar ziyaret edersem yine } \\
\text { aynı rehberle tura çıkmayı isterim. }\end{array}$ & 4,03 & 1,200 & \\
\hline & TOPLAM & 4,26 & 1,030 & \\
\hline
\end{tabular}

Destinasyon sadakati ölçeğinin aritmetik ortalama ve standart sapma değerleri incelendiğinde "Bu turu insanlara tavsiye edeceğim" ifadesinin 4,44 oran ile en yüksek değere sahip ifade olduğu görülmektedir. Bununla birlikte "Burayı tekrar ziyaret edersem yine aynı rehberle tura çıkmayı isterim" ifadesinin 4,03 değer oranı ile ifadeler arasındaki en düşük ifadedir. Bu ölçekte yer alan 3 ifadenin alfa değeri 0,77 olduğu görülmektedir. Cronbach Alfa değeri 0,70 ' den yüksek olduğu göz önünde bulundurulduğunda ölçeğin tutarlı ve güvenilir olduğu söylenebilmektedir (İslamoğlu ve Alnıaçık, 2014: 283).

Çalışmanın amacına uygun şekilde belirlenen değişkenler arasında herhangi bir ilişkinin var olup olmadığını test etmek amacıyla korelasyon testi uygulanmıştır. Korelasyon testi içerisinde veriler normal bir dağılım göstermiyorsa Spearman korelasyon katsayısına bakılmaktadır. Eğer veriler normal bir dağılım gösteriyorsa Pearson korelasyon katsayısı göz önünde bulundurulmaktadır. Veriler normal dağılım gösterdiği için ilişki testlerinde Pearson korelasyon 
katsayısı alınmıştır. Buna göre katsayının $-1,00$ veya 1,00 olması durumunda aralarındaki ilişkinin mükemmel olumlu ya da olumsuz olduğunu göstermektedir. Katsayının 0,00 olması durumunda aralarında ilişki olmadı $\breve{g} 1$ anlamına gelmektedir. Korelasyon katsayısı 0,00-0,30 aralığında olması düşük derece ilişki olduğunu göstermektedir. Katsayının 0,30-0,70 aralığında olması orta derece, 0,70-1,00 aralığında olması durumunda ise aralarında yüksek derece ilişki bulunduğu sonucunu göstermektedir (Büyüköztürk, 2017: 31). Tablo 6'da yorumlayıcı rol ölçeği ile turist memnuniyeti ölçeği arasındaki ilişkiye yönelik korelasyon analizi sonuçlarına yer verilmektedir.

Tablo 6. Yorumlayıcı Rol ve Turist Memnuniyeti Ölçeklerine Yönelik Korelasyon Testi Bulguları

\begin{tabular}{|l|c|c|}
\hline DEĞİŞKENLER & Yorumlayıcı Rol & Turist Memnuniyeti \\
\hline Yorumlayıcı Rol & $\mathbf{1}$ & $0,849^{* *}$ \\
\hline Turist Memnuniyeti & $0,849^{* *}$ & $\mathbf{1}$ \\
\hline N & 391 & 391 \\
\hline
\end{tabular}

**: $p<0,01$

Tablo 6'ya bakıldığında yorumlayıcı rol ve turist memnuniyeti arasında $\left(\mathrm{r}=0,849^{* *} ; \mathrm{p}<0,01\right)$ yüksek düzeyde olumlu ve anlamlı bir ilişki görülmektedir. Tablo $7^{\prime}$ de yorumlayıcı rol ölçeği ve destinasyon sadakati ölçeği arasındaki ilişkiye yönelik korelasyon analizi sonuçları yer almaktadir.

Tablo 7. Yorumlayıcı Rol ve Destinasyon Sadakati Ölçeklerine Yönelik Korelasyon Testi Bulguları

\begin{tabular}{|l|c|c|}
\hline DEĞISSEKNLER & Yorumlayıcı Rol & Destinasyon Sadakati \\
\hline Yorumlayıcı Rol & $\mathbf{1}$ & $0,746^{* *}$ \\
\hline Destinasyon Sadakati & $0,746^{* *}$ & $\mathbf{1}$ \\
\hline N & 391 & 391 \\
\hline
\end{tabular}

**: $p<0,01$

Tablo $7^{\prime}$ de görüldügü üzere yorumlayıcı rol ve destinasyon sadakati arasında $\left(\mathrm{r}=0,746^{* *} ; \mathrm{p}<0,01\right)$ yüksek düzeyde olumlu ve anlamlı bir ilişki olduğu sonucuna ulaşılmaktadır. Tablo 8 ' de turist memnuniyeti ölçeği ile destinasyon sadakati ölçeği arasındaki ilişkiye yönelik korelasyon analizi sonuçları görülmektedir.

Tablo 8. Turist Memnuniyeti ve Destinasyon Sadakati Ölçeklerine Yönelik Korelasyon Testi Bulguları

\begin{tabular}{|l|c|c|}
\hline DEĞIŞKENLER & Turist Memnuniyeti & Destinasyon Sadakati \\
\hline Turist Memnuniyeti & $\mathbf{1}$ & $0,749^{* *}$ \\
\hline Destinasyon Sadakati & $0,749^{* *}$ & $\mathbf{1}$ \\
\hline $\mathrm{N}$ & 391 & 391 \\
\hline
\end{tabular}

**: $p<0,01$ 
Regresyon analizi, bir veya birden fazla metrik bağımsız değişken ile bir bağımlı değişken arasındaki ilişkiyi tespit etmek amacıyla yapılan istatistiksel bir yöntem olarak tanımlanmaktadır (Hair vd., 1998: 155). Daha kısa ifadeyle regresyon analizi, bağımlı bağımsız değişken ayrımı yaparak değişkenlerin birbirleri arasındaki ilişkiyi ortaya koyan bir testtir (Büyüköztürk, 2017, s. 92). Turist rehberlerinin yorumlayıcı rolünün destinasyon sadakati ilişkisinde turist memnuniyetinin aracılık rolünü tespit etmek için Baron ve Kenny (1986)'nin geliştirmiş oldukları aracı değişken analiz yöntemi kullanılmaktadır. Fakat Baron ve Kenny (1986)'e göre bağımlı ve bağımsız değişkenler arasındaki bir aracı değişkenin olmasından bahsedilebilmesi için bazı ön koşullar gerekmektedir. Ön koşullar şu şekildedir:

- Aracı değişkendeki bir değişiklik, bağımlı değişkende de değişikliğe neden olmalıdır.

- Bağımsız değişkendeki bir değişiklik, aracı değişkende de değişikliğe neden olmalıdır.

- Aracı değişken ve bağımsız değişken birlikte analiz edildiğinde bağımsız değişkenin bağımlı değişken üzerindeki etkisinin azalması veya tamamen ortadan kalması gerekmektedir. Etki tamamen ortadan kalkarsa, aracı değişkenin tam aracılık etkisi olduğu söylenebilmektedir. Eğer etki azalırsa farklı aracı değişkenlere sahip olduğuna işaret etmektedir. Tablo 9'da turist rehberlerinin yorumlayıcı rolünün turist memnuniyeti üzerine etkisinin regresyon analizi sonuçları görülmektedir.

Tablo 9. Yorumlayıcı Rol ve Turist Memnuniyeti Arasındaki Regresyon Analizi

\begin{tabular}{|c|c|c|c|c|}
\hline Model 1 & $\mathbf{R}$ & $\mathbf{R}^{\mathbf{2}}$ & Düzeltilmiş $\mathbf{R}^{\mathbf{2}}$ & Standart Hata \\
\hline & 0,849 & 0,722 & 0,721 & 0,48571 \\
\hline
\end{tabular}

Bağımsız Değişken: Yorumlayıcı Rol

\begin{tabular}{|c|c|c|c|c|c|}
\hline \multicolumn{6}{|c|}{ ANOVA } \\
\hline & $\begin{array}{l}\text { Kareler } \\
\text { Toplamı }\end{array}$ & df & Ortalama kare & $\mathbf{F}$ & Sig. \\
\hline Regresyon & 237,816 & 1 & 237,816 & 1008,054 & 0,000 \\
\hline Artık Değer & 91,771 & 389 & 0,236 & & \\
\hline Toplam & 329,587 & 390 & & & \\
\hline
\end{tabular}

Bağımsız Değişken: Yorumlayıcı Rol

\begin{tabular}{|c|c|c|c|c|c|}
\hline \multirow{2}{*}{ Model 1 } & \multicolumn{2}{|c|}{$\begin{array}{c}\text { Standardize Edilmemiş } \\
\text { Katsayı }\end{array}$} & $\begin{array}{c}\text { Standardize } \\
\text { Edilmiş Katsayı }\end{array}$ & \multirow{2}{*}{ t } & \multirow{2}{*}{ Sig. } \\
\cline { 2 - 4 } & B & Standart Hata & BETA & & \\
\hline Sabit & $-0,089$ & 0,144 & & $-0,621$ & 0,535 \\
\hline Yorumlayıcı Rol & 1,027 & 0,032 & 0,849 & 31,750 & 0,000 \\
\hline
\end{tabular}

Bağımlı Değişken: Turist Memnuniyeti

Turist rehberlerinin yorumlayıcı rolünün, turist memnuniyeti üzerindeki etkisine yönelik oluşturulan H1 hipotezi "Turist rehberlerinin yorumlayıct rolü turist memnuniyetini etkilemektedir" şeklinde belirlenmiştir. Tablo $9^{\prime}$ da yer alan $\mathrm{R}^{2}$ değeri dikkate alındığında yorumlayıcı rolün turist memnuniyeti üzerindeki değişimin $\% 72$ 'sini açıkladığı tespit edilmiştir. ANOVA testi sonuçlarına bakıldığında incelenen modelin genel olarak anlamlı olduğu görülmektedir ( $F=1008,054 ; \mathrm{p}<0,001)$.

Hemen altında yer alan regresyon katsayılarına bakıldığında anket katılımcılarının yorumlayıcı role ilişkin algılamalarındaki bir birimlik artış, turist memnuniyetini 1,027 oranında arttırmaktadır. Tüm bunlar ışı̆̆ında araştırmanın H1 hipotezi kabul edilmiştir. Tablo 10'da turist 
memnuniyetinin destinasyon sadakati üzerindeki etkisinin regresyon analizi bulgularına yer verilmektedir.

Tablo 10. Turist Memnuniyeti ve Destinasyon Sadakati Arasındaki Regresyon Analizi

\begin{tabular}{|c|c|c|c|c|}
\hline Model 1 & $\mathbf{R}$ & $\mathbf{R}^{\mathbf{2}}$ & Düzeltilmiş $\mathbf{R}^{\mathbf{2}}$ & Standart Hata \\
\hline & 0,749 & 0,561 & 0,560 & 0,57025 \\
\hline
\end{tabular}

Bağımsız Değişsen: Turist Memnuniyeti

\begin{tabular}{|c|c|c|c|c|c|}
\hline \multicolumn{7}{|c|}{ ANOVA } \\
\hline & $\begin{array}{c}\text { Kareler } \\
\text { Toplamı }\end{array}$ & df & Ortalama kare & F & Sig. \\
\hline Regresyon & 161,461 & 1 & 161,461 & 496,518 & 0,000 \\
\hline Artık Değer & 126,498 & 389 & 0,325 & & \\
\hline Toplam & 287,959 & 390 & & & \\
\hline
\end{tabular}

Bağımsız Değişken: Turist Memnuniyeti

\begin{tabular}{|c|c|c|c|c|c|}
\hline \multirow{2}{*}{ Model 1 } & \multicolumn{2}{|c|}{$\begin{array}{c}\text { Standardize Edilmemiş } \\
\text { Katsayı }\end{array}$} & $\begin{array}{c}\text { Standardize } \\
\text { Edilmiş Katsayı }\end{array}$ & \multirow{2}{*}{$\mathbf{t}$} & \multirow{2}{*}{ Sig. } \\
\cline { 2 - 5 } & B & $\begin{array}{l}\text { Standart } \\
\text { Hata }\end{array}$ & BETA & \\
\hline Sabit & 1,172 & 0,142 & & 8,265 & 0,000 \\
\hline Turist Memnuniyeti & 0,700 & 0,031 & 0,749 & 22,283 & 0,000 \\
\hline
\end{tabular}

Bağımlı Değişken: Destinasyon Sadakati

Tablo 11. Yorumlayıcı Rol ve Destinasyon Sadakati Arasındaki Regresyon Analizi

\begin{tabular}{|c|c|c|c|c|}
\hline Model 1 & $\mathbf{R}$ & $\mathbf{R}^{\mathbf{2}}$ & Düzeltilmiş R & Standart Hata \\
\hline & 0,746 & 0,557 & 0,556 & 0,57260 \\
\hline
\end{tabular}

Bağımsız Değişken: Yorumlayıcı Rol

\begin{tabular}{|c|c|c|c|c|c|}
\hline \multicolumn{7}{|c|}{ ANOVA } & Sig. \\
\hline & $\begin{array}{c}\text { Kareler } \\
\text { Toplamı }\end{array}$ & df & Ortalama kare & F & \\
\hline Regresyon & 160,418 & 1 & 160,418 & 489,272 & 0,000 \\
\hline Artık Değer & 127,541 & 389 & 0,328 & & \\
\hline Toplam & 287,959 & 390 & & & \\
\hline
\end{tabular}

Bağımsız Değişken: Yorumlayıcı Rol

\begin{tabular}{|c|c|c|c|c|c|}
\hline \multirow{2}{*}{ Model 1 } & \multicolumn{2}{|c|}{$\begin{array}{c}\text { Standardize Edilmemiş } \\
\text { Katsayı }\end{array}$} & $\begin{array}{c}\text { Standardize } \\
\text { Edilmiş Katsayı }\end{array}$ & \multirow{2}{*}{$\mathbf{t}$} & \multirow{2}{*}{ Sig. } \\
\cline { 2 - 5 } & B & $\begin{array}{l}\text { Standart } \\
\text { Hata }\end{array}$ & BETA & \\
\hline Sabit & 0,562 & 0,170 & & 3,307 & 0,001 \\
\hline Yorumlayı1 Rol & 0,844 & 0,038 & 0,746 & 22,119 & 0,000 \\
\hline
\end{tabular}

Bağımlı Değişken: Destinasyon Sadakati

Turist memnuniyetinin destinasyon sadakati üzerindeki etkiyi belirlemek amaciyla oluşturulan H2 hipotezi "Turist memnuniyeti turist destinasyon sadakatini etkilemektedir" şeklinde belirlenmiştir. Tablo 10 'a bakıldığında destinasyon sadakatine yönelik değişimin $\% 56,1^{\prime}$ i turist memnuniyeti ile 
açiklanabilmektedir. ANOVA sonuçlarına bakıldığında bu modelin istatistiksel olarak anlamlı olduğu tespit edilmiştir $(\mathrm{F}=496,518 ; \mathrm{p}<0,001)$. Bununla beraber regresyon katsayıları incelendiğinde turist memnuniyetindeki bir birimlik artışın destinasyon sadakati üzerinde 0,700 oranında artış göstereceği görülmektedir. Tüm bunlar ışığında analiz sonuçlarında turist memnuniyetinin destinasyon sadakati üzerinde olumlu yönde anlamlı bir etkinin varlığı tespit edilmiştir. Bu kapsamda H2 hipotezi kabul edilmiştir. Tablo 11'de turist rehberlerinin yorumlayıcı rolünün destinasyon sadakati üzerine etkisine yönelik regresyon analizi bulguları yer almaktadır.

Yorumlayıcı rolün destinasyon sadakati üzerindeki etkisine yönelik H3 hipotezi "Turist rehberlerinin yorumlayıc rolü turist destinasyon sadakatini etkilemektedir" olarak belirlenmiştir. H3 hipotezini test etmek amacıyla basit regresyon analizi yapılmıştır. Analiz sonucuna göre $\mathrm{R}^{2}$ değeri \%55,7 olarak görülmektedir. Bu oran yorumlayıcı rolün destinasyon sadakati üzerindeki değişim oranını göstermektedir. ANOVA bulgularına bakıldığında modelin istatistiksel olarak anlamlı olduğu tespit edilmiştir ( $\mathrm{F}=489,272 ; \mathrm{p}<0,001)$. ANOVA bulgularının altında yer alan regresyon katsayısı incelendiğinde yorumlayıcı roldeki bir birimlik artışın destinasyon sadakati üzerinde olumlu şekilde 0,746 oranında bir artışa sebep olacağı görülmektedir. Bir diğer ifade ile turist rehberlerinin yorumlayıcı rolünün destinasyon sadakati üzerinde anlamlı bir etkisi vardır. Tüm bulgular ışığında H3 hipotezi kabul edilmektedir. Tablo 12'de yorumlayıcı rolü, turist memnuniyeti ve destinasyon sadakati arasındaki ilişkinin belirlenmesi amacıyla yapılan çoklu regresyon analiz bulguları verilmektedir.

Tablo 12. Yorumlayıcı Rol - Turist Memnuniyeti ve Destinasyon Sadakati Arasındaki Çoklu Regresyon Analizi

\begin{tabular}{|c|c|c|c|c|}
\hline Model 1 & $\mathbf{R}$ & $\mathbf{R}^{\mathbf{2}}$ & Düzeltilmiş $\mathbf{R}^{\mathbf{2}}$ & Standart Hata \\
\hline & 0,777 & 0,604 & 0,602 & 0,54184 \\
\hline
\end{tabular}

Bağımsız Değişken: Yorumlayıcı Rol - Turist Memnuniyeti

\begin{tabular}{|c|c|c|c|c|c|}
\hline \multicolumn{7}{|c|}{ ANOVA } \\
\hline & $\begin{array}{c}\text { Kareler } \\
\text { Toplamı }\end{array}$ & df & Ortalama kare & F & Sig. \\
\hline Regresyon & 174,046 & 2 & 87,023 & 296,409 & 0,000 \\
\hline Artık Değer & 113,913 & 389 & 0,294 & & \\
\hline Toplam & 287,959 & 390 & & & \\
\hline
\end{tabular}

Bağımsız Değişken: Yorumlayıcı Rol - Turist Memnuniyeti

\begin{tabular}{|c|c|c|c|c|c|}
\hline \multirow{2}{*}{ Model 1 } & \multicolumn{2}{|c|}{ Std. Edilmemiş Katsayı } & \multirow{2}{*}{$\begin{array}{c}\text { Std. Edilmiş } \\
\text { Katsayı }\end{array}$} & \multirow{2}{*}{ t } & \multirow{2}{*}{ Sig. } \\
\cline { 2 - 4 } & B & $\begin{array}{l}\text { Standart } \\
\text { Hata }\end{array}$ & BETA & & \\
\hline Sabit & 0,596 & 0,161 & & 3,708 & 0,000 \\
\hline Yorumlayıc1 Rol & 0,448 & 0,068 & 0,396 & 6,547 & 0,000 \\
\hline Turist Memnuniyeti & 0,385 & 0,057 & 0,412 & 6,813 & 0,000 \\
\hline
\end{tabular}

Bağımlı Değişken: Destinasyon Sadakati

Yorumlayıcı rol, turist memnuniyeti ve destinasyon sadakatine yönelik H4 hipotezi "Turist rehberlerinin yorumlayıcı rolü, turist memnuniyeti aracllı̆̆ıla turistlerin destinasyon sadakatini 
etkilemektedir" şeklinde geliştirilmiştir. Buna bağlı olarak Tablo 12'deki analizler incelendiğinde yorumlayıcı rol ve turist memnuniyeti bağımsız değişkenlerindeki $\mathrm{R}^{2}$ değeri, destinasyon sadakati bağımlı değişkeni üzerindeki değişimin $\% 60,4^{\prime}$ ünü temsil ettiği görülmektedir. ANOVA testi sonucuna göre belirtilen modelin istatistiki olarak anlamlı olduğu tespit edilmiştir. ( $F=296,409 ; p<0,001)$.

Daha önce yapılan yorumlayıcı rol bağımsız değişkeninin destinasyon sadakati üzerindeki etkisinde yer alan regresyon katsayısı $\mathrm{B}=0,844$ - Beta $=0,746$ olarak görülmekte iken turist memnuniyeti aracı değişkeni yapılan analize dahil edildiğinde $\mathrm{B}=0,448$ - Beta $=0,396$ şeklinde azaldığı görülmektedir. Bu katsayılara bakarak turist memnuniyetinin yorumlayıcı rol ile destinasyon sadakati üzerinde aracı değişken rolü olduğu tespit edilmiştir. Baron ve Kenny (1986) çalışmalarında aracı değişkenin analize dahil edilmesi durumunda regresyon katsayısında azalma görülürse "kısmi aracılık etkisi" olduğu vurgusu yapmaktadırlar. Tüm bunlar ışığında yapılan analiz sonuçlarından hareketle turist memnuniyeti aracı değişkeninin kısmi aracılık etkisine sahip olduğu görülmektedir. Analiz sonucuna göre $\mathrm{H} 4$ hipotezi kabul edilmiştir. Şekil 2 'de araştırmanın sonuç modeli yer almaktadır. Tablo 10'da araştırma hipotezlerinin kabul-red durumu görülmektedir. Araştırma sonuçlarına göre belirlenen tüm hipotezler kabul edilmiştir.

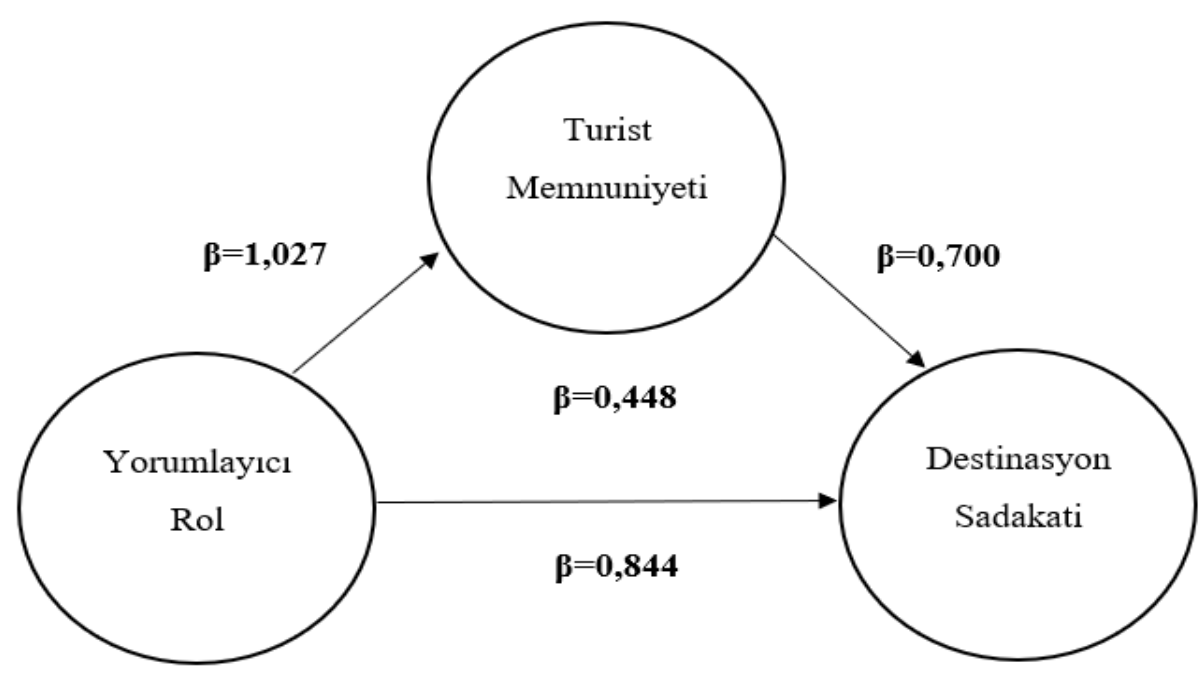

Şekil 2. Araştırmanın Sonuç Modeli

\section{TARTIŞMA, SONUÇ ve ÖNERİLER}

Yapılan çalışma, ülkemizde mesleklerini icra eden turist rehberlerinin yorumlayıcı rolünün turist memnuniyeti aracılık rolü üzerinden ziyaretçilerin gittikleri destinasyona yönelik sadakat düzeyine etkisini ortaya koymaktır. Bu doğrultuda yorumlayıcı rol ve destinasyon sadakati ile ilgili alan yazından yola çıkılarak, araştırmanın örneklemini oluşturan Çanakkale Savaşları Gelibolu Tarihi Alanı'nı ziyaret eden turistlerin anket formlarına vermiş oldukları cevaplar ışığında veriler edinilmiştir. Edinilen veriler istatistiki birtakım analizlere tabi tutulmakla birlikte bulgular saptanmış ve çeşitli sonuçlara ulaşılmıştır.

Anket formu aracılığıyla sosyo-demografik özellikler, ziyaretçilerin önceki ziyaret sıklıkları ve memnuniyetleri, rehberlerin yorumlayıcı rolü, turist memnuniyeti ve destinasyon sadakatine yönelik bilgiler elde edilmiştir. Anket katılımcılarının sosyo-demografik özelliklerine 
bakıldığında kadın katılımcıların erkek katılımcılara göre çoğunluğu oluşturduğu görülmektedir. Daha önce yapılan çalışmalarda da benzer sonuçlara ulaşılmaktadır (Poudel ve Nyaupane, 2015; Kuo vd., 2016; Çapar ve Yenipınar, 2017). Yaş ile ilgili bulgulara bakıldığında 19-28 yaş arasındaki katılımcıların çoğunlukta olduğu sonucuna ulaşılmaktadır. Bununla birlikte katılımcıların eğitim düzeylerine bakıldığında üniversite seviyesindeki katılımcların sayıca yüksek olduğu görülmektedir. Benzer bulgulara Kuo ve diğerleri (2016) ile Çapar ve Yenipınar'ın (2017) çalışmalarına da rastlanmaktadır. Katılımcıların meslekleri göz önünde bulundurulduğunda öğrencilerin çoğunluğu oluşturduğu anlaşılmaktadır. Öğrenciye en yakın meslek ise özel sektör çalışanlarından oluşmaktadır. Meslek kısmında "diğer" ifadesini işaretlemiş katılımcıların arasında "kabin memuru" ve "çiftçi" gibi meslekler de bulunmaktadır. Çanakkale Savaşları Gelibolu Tarihi Alanı'na gerçekleştirilen turların büyük kısmının bu dönemde öğrenci ağırlıklı olduğu söylenebilmektedir. Dolayısıyla katılımcıların büyük çoğunluğunun bekar olduğu sonucuna ulaşılmıştır. Anketlerin uygulandığ Gelibolu Tarihi Alanı'nı ziyaret eden kişi sayısı 240 olarak tespit edilmiştir. Bu oran tüm katılımcıların \%61,4'ünü kapsamaktadır. Daha önce ziyaret gerçekleştirmiş katılımcıların ziyaret sıklıkları çoğunlukla 2 kez olduğu görülmektedir. 48 kişi 3 kez, 49 kişi ise 4 kez ve üzeri ziyaret gerçekleştirmişlerdir. Katılımcıların, daha önce Çanakkale'ye yönelik rehberli bir tura katılıp katılmadıkları sorusuna çoğunlukla evet yanıtını verdiği görülmektedir. Evet yanıtını veren katılımcıların büyük çoğunluğunun katıldıkları turdan memnun ayrıldıkları görülmektedir. Buradan hareketle anket katılımcılarının çoğunluğunun rehberli bir tura aşina olduğu yorumu yapılabilmektedir.

Anket katılımcılarının cevaplamış olduğu ifadelerin ortalama ve standart sapma değerlerine bakıldığında, tur sırasında rehberin yorumlayıcı rolüne yönelik bazı ifadelere karşı daha olumlu bir tutum sergiledikleri tespit edilmiştir. En yüksek ortalamaya sahip ifadeler arasında turist rehberinin yorumlarının ilgi çekici olduğu ve rehberin yorumlarının içeriği ile konu arasında artık bağlantı kurabilecekleri konuları yer almaktadır. Buradan hareketle, anket katılımcılarının daha önce sahip olmadıkları bilgileri rehberin yorumlarıyla birlikte öğrenip daha anlaşılır ve ilginç buldukları sonucuna ulaşılmaktadır. Turist memnuniyeti ifadelerine bakıldığında katılımcıların tur sırasında hoş duygular hissettikleri ifadesinin ön plana çıktığı görülmektedir. Ayrıca bu orana en yakın ifade olarak turu satın aldıkları için memnun oldukları ifadesinin olduğu tespit edilmiştir. Destinasyon sadakati ifadelerinde bakıldığında katılımclara ait en çok orana sahip ifade ise katıldıkları turu çevrelerine tavsiye edecekleri ifadesi olduğu görülmektedir. Ancak Çanakkale Savaşları Gelibolu Tarihi Alanı'nı tekrar ziyaretleri söz konusu olduğunda yine aynı rehberle çıkma isteği ifadesinin diğer ifadelere göre daha az ortalamaya sahip olduğu görülmektedir. Buradan hareketle katılımcıların, rehberin yaptıkları yorumlardan olumlu yönde etkilenip memnuniyet hissetmeleri, bölgeyi yeniden ziyarette aynı rehberle çıkma isteğini pek etkilemediği söylenebilmektedir.

Yorumlayıcı rol ve turist memnuniyeti değişkenlerine yönelik ilişki testleri sonuçlarına göre, iki değişken arasında yüksek düzeyde olumlu ve anlamlı bir ilişki tespit edilmiştir. Bununla birlikte yorumlayıcı rol ile destinasyon sadakati arasında da yüksek düzeyde olumlu ve anlamlı bir ilişki olduğu görülmüştür. Son olarak turist memnuniyeti ve destinasyon sadakati arasında yine yüksek düzeyde olumlu ve anlamlı bir ilişki olduğu tespit edilmiştir. Baron ve Kenny (1986) tarafından geliştirilmiş olan aracılık etkisi yönteminden hareket ederek yorumlayıcı rolün destinasyon sadakati üzerindeki etkisine turist memnuniyeti aracılık rolü regresyon analizi kullanılarak ortaya çıkarılmıştır. Çıkan sonuçlara bakılarak, katılımcıların yorumlayıcı role yönelik algılarının destinasyon sadakati üzerinde etkili olduğu, ayrıca turist memnuniyetinin bu etkiye aracılık rolü ile katkı yaptığı görülmektedir. Kuo ve diğerleri'nin (2016) yapmış oldukları 
çalışmada da benzer sonuçlar ifade edilmektedir. Çıkan sonuçlardan hareketle çalışmanın amaçları doğrultusunda belirtilmiş olan dört hipotez de kabul edilmiştir.

Çalışma sonuçları doğrultusunda Turist Rehberleri Birliği'ne, turist rehberliği eğitimi veren kurumlara ve turist rehberlerine öneriler;

- Turist rehberleri bir bilgiyi direkt olarak vermekten ziyade kendi yorumlarını katarak misafirlerin anlayacağı şekilde onlara aktarabilmesi gerekmektedir.

- Turistlerin bölgeye karşı sürekliliklerini sağlamak için memnuniyetlerinin arttırılması gerekmektedir. Bunu da turist rehberi yoluyla yapmak tüm kurumlara kolaylık sağlayabilmektedir. Dolayısıyla nitelikli rehberleri yetiştirmek kurumların görevleri arasında olması gerekmektedir.

- Araştırma sonucundan hareketle, turist rehberlerinin yorumlayıcı rolünün yüksek düzeyde olumlu algılanmasının görülmesi üzerine, turist rehberliği alanında ön lisans, lisans ve yüksek lisans eğitimi veren eğitim kurumları, teorik eğitimin yanında rehber adaylarına yönelik yorumlama yeteneğini geliştirecek çeşitli pratik eğitimler de vermeleri gerekmektedir.

- Üniversitede verilen eğitimlerin yanında, meslekte aktif çalışan rehberlere yönelik yorumlama yeteneklerini geliştirebilecek çeşitli pratik eğitimler Turist Rehberleri Birliği tarafından verilmelidir.

- Meslek odaları turist rehberlerinin yorumlama yeteneklerini geliştirmeleri adına çeşitli kurslar ve seminerler açmaları gerekmektedir.

- Turist rehberlerinin çalışma şartları ve imkanları acentalar tarafından iyileştirmesi gerekmektedir. Şartlar iyileştikçe turist rehberleri misafirlerine yönelik daha rahat bir yorumlama ortamı sağlayabilmektedir. Bu sayede destinasyona sadakat eğilimi gösteren misafirlerin turu satın aldıkları acentaya karşı da sadakat göstermeleri mümkün olabilmektedir.

- Çanakkale Savaşları Gelibolu Tarihi Alanını ziyaret eden turistlerin tekrar ziyaret etme durumlarında aynı rehberle tur yapma isteklerinin düşük olduğu görülmektedir. Bu duruma yönelik turist rehberleri, tarihi alan hakkında merak uyandıracak anlatımlar ve gelecekte tarihi alanda yapılacak olan projelerden bahsetmeli, kişisel bazda memnuniyet sağlamak için çaba sarf etmelidir.

- 59 yaş ve üstü ziyaretçilerin diğer ziyaretçilere göre yorumlayıcı role yönelik algılamaları daha olumlu olarak görülmektedir. Turist rehberlerinin yorumlama yaparken genç katılımcilara yönelik ifadeler kullanmaları gerekmektedir. Buradan hareketle, turist rehberleri güncel gelişmeler ve gençlere yönelik güncel haberleri takip etmelidir.

Çalışma sonuçları doğrultusunda gelecek çalışmalara yönelik öneriler;

- Bu çalışma Çanakkale Savaşları Gelibolu Tarihi Alanına yönelik yapılmış bir çalışmadır. Gelecekte farklı destinasyonlar için farklı değişkenler kullanılarak tekrar yapılabilir.

- Turist rehberlerinin birçok rolü bulunmaktadır. Hem aynı tarihi alan için hem de farklı alanlar için birçok role yönelik çalışmalar yapılabilir. Buna örnek olarak, kültürel arabulucu rolünün destinasyon sadakatine etkisi olabilir.

- Turist rehberlerinin bir diğer rolü olan kaynak yönetimi rolünden yola çıarak, özellikle Milli Parklar ve Alan Başkanlıklarına yönelik araştırmalar yapılmalıdır.

\section{KAYNAKÇA}

Ahipaşaoğlu, S. (2006). Turizmde Rehberlik. (11. Basım). Ankara: Gazi Kitapevi.

Anand, A. (1997). Advance Dictionary of Tourism. New Delhi: Sarap \& Sons. 
Anastassova, L. (2004). The Loyal Tourist as an Important Partner in The New Generation of Partnerships on Local Level for Destination Development and Marketing. Proceedings of the ATLAS Annual Conference, Networking \& Partnerships in the Destination Development \& Management, Italy: 415-424.

Ap, J. and Wong, K. F. (2001). Case Study on Tour Guiding: Professionalism, Issues and Problems. Tourism Management, 22(5): 551-563.

Aslan, Ş. (2008). Örgütsel Vatandaşlık Davranışı ile Örgütsel Bağlllık ve Mesleğe Bağlılık Arasındaki İlişkilerin Araştırılması. Celal Bayar Üniversitesi İ.I.B.F. Yönetim ve Ekonomi Dergisi, 15(2): 163-179.

Avcıkurt, C. (2015). Turizm Sosyolojisi: Genel ve Yapısal Yaklaşım. Ankara: Detay Yayıncılık.

Baron, R. M. and Kenny, D. A. (1986). The Moderator-Mediator Variable Distinction in Social Psychological Research: Conceptual, Strategic and Statistical Considerations. Journal of Personality and Social Psychology, 51(6): 1173-1181.

Batman, O., Yıldırgan, R. ve Demirtaş, N. (2000). Turizm Rehberliği. Adapazarı: Değişim Yayınları.

Bayram, N. (2004). Sosyal bilimlerde SPSS ile Veri Analizi. Bursa: Ezgi Kitabevi.

Benli, S. (2014). Yöresel Lezzet Deneyiminin Destinasyon İmajı ve Destinasyon Sadakati Üzerine Etkisi: Mersin'i Ziyaret Eden Yerli Turistler Üzerinde Bir Araştırma. Yüksek Lisans Tezi. Mersin: Mersin Üniversitesi, Sosyal Bilimler Enstitüsü.

Birkök, M. C. (2004). Sosyal Rol ve İş Bölümü. International Journal of Human Sciences, 1(1): 1-10.

Buhalis, D. (2000). Marketing the Competitive Destination of the Future. Tourism Management, 21(1): $97-116$.

Büyüköztürk, Ş. (2017). Sosyal Bilimler İçin Veri Analizi El Kitabı. Ankara: Pegem Yayıncılık.

Chen, C. F. and Chen, F. S. (2010). Experience Quality, Perceived Value, Satisfaction and Behavioral Intentions for Heritage Tourists. Tourism Management, 31(1): 29-35.

Croes, R., Shani, A. and Walls, A. (2010). The Value of Destination Loyalty: Myth or Reality?. Journal of Hospitality Marketing, 19(2): 115-136.

Çapar, G. ve Yenipınar, U. (2017). Kültürel ve Doğal Mirasın Sürdürülebilirliğinde Turist Rehberinin Rolüne İlişkin Turist Alg1sı. Balıkesir Üniversitesi Sosyal Bilimler Enstitüsü Dergisi, 20(38): 397-424.

Çimrin, H. (1995). Turizm ve Turist Rehberliğinin Abc'si. Antalya: Akdeniz Kitabevi.

Gürün, M. (2014). Termal Turizm İşletmelerine Gelen Ziyaretçilerin Tatmin Düzeylerinin Destinasyon Sadakati Üzerindeki Etkisi: Niğde Çiftehan Kaplıcalarında Bir Uygulama, Yüksek Lisans Tezi, Niğde: Niğde Üniversitesi, Sosyal Bilimler Enstitüsü. 
Güzel, F. (2007). Türkiye Imajının Geliştirilmesinde Profesyonel Turist Rehberlerinin Rolü, Yüksek Lisans Tezi, Balıkesir: Balıkesir Üniversitesi, Sosyal Bilimler Enstitüsü.

Hair, J. F., Anderson, R. E., Tatham, R. L. and Black, W. C. (1998). Multivariate Data Analysis. (7. Edition). Boston: Pearson.

Hu, W. and Wall, G. (2012). Interpretative Guiding and Sustainable Development: A Framework. Tourism Management Perspective, 4: 80-85.

Hu, Y. and Ritchie, J. R. B. (1993). Measuring Destination Attractiveness: A Contextual Approach. Journal of Travel Research, 32(2): 25-34.

https://catab.ktb.gov.tr/TR-196178/istatistikler.html [Erişim Tarihi: 10.03.2020].

İslamoğlu, A. H. ve Alnıaçık, Ü. (2014). Sosyal Bilimlerde Araştırma Yöntemleri. İstanbul: Beta Yayıncilik.

Karasar, N. (2016). Bilimsel Araştırma Yöntemleri, (31. Basım). Ankara: Nobel Akademik Yayıncılık.

Kastenholz, E.; Carneiro, M. J. and Eusebio, C. (2006). Studying Visitors' Loyalty to Rural Tourist Destinations. Kozak, M. and Andreu, L. (Ed.) Progress in Tourism Marketing, içinde (ss. 239-253) Amsterdam: Elsevier.

Kılıç, B. (2011). Destinasyon ziyaretçilerinin Sosyo-Demografik Özelliklerinin Sadakat Eğilimleri Üzerine Etkisi. Selçuk Üniversitesi Sosyal Bilimler Enstitüsü Dergisi, 26: 239-252.

Kozak, M. (2017). Bilimsel Araştırma: Tasarım, Yazım ve Yayım Teknikleri. (3. Basım). Ankara: Detay Yayincilik.

Köroğlu, Ö. (2013). Turist Rehberlerinin İş Yaşamındaki Rolleri Üzerine Kavramsal Bir Değerlendirme, Pamukkale Üniversitesi Sosyal Bilimler Enstitüsü Dergisi, 16: 91-112.

Kuo, N. Chang, K. C., Cheng, Y. S. and Lin, J. C. (2016). Effects of Tour Guide Interpretation and Tourist Satisfaction on Destination Loyalty in Taiwan's Kinmen Battlefield Tourism: Perceived Playfulness and Perceived Flow as Moderators. Journal of Travel and Tourism Marketing, 33(1): 103122.

Martin, H. S., Collado, J. and del Bosque, I. R. (2013). An Exploration of The Effects of Past Experience and Tourist Involvement on Destination Loyalty Formation. Current Issues in Tourism, 16(4): 327-342.

McDonnell, I. (2001). The Role of The Tour Guide in Transferring Cultural Understanding. School of Leisure, Sport and Tourism Working Paper Series, 3: 1-16.

McDowall, S. (2010). International Tourist Satisfaction \& Loyalty: Bangkok, Thailand. Asia Pacific Journal of Tourism Research, 15(1): 21-42.

McKercher, B. and Guillet, B. D. (2010). Are Tourists or Markets Destination Loyal?. Journal of Travel Research, 50(2): 121-132. 
Moscardo, G. (2003). Interpretation and Sustainable Tourism: Functions, Examples and Principles. The Journal of Tourism Studies, 14(1): 112-123.

Nelson, V. (2003). Representation and Images of Ecotourism in Grenada. Master Thesis, Greenville: East Carolina University.

Oppermann, M. (2000). Tourism Destination Loyalty. Journal of Travel Research, 39(1): 78-84.

Özkan, Ş. (2008). Rol Çatışması ve Rol Belirsizliğinin Hekim ve Hemşirelerin Tükenmişlik Düzeyleri Üzerine Olan Etkisi. Yayınlanmamış Yüksek Lisans Tezi, Ankara: Hacettepe Üniversitesi.

Poudel, S. and Nyaupane, G. P. (2013). The Role of Interpretative Tour Guiding in Sustainable Destination Management: A Comparison Between Guided and Nonguided Tourists. Journal of Travel Research, 52(5): 659-672.

Rabotić, B. (2010). Tourist Guides in Contemporary Tourism. International Conference on Tourism and Environment Sarajevo, Bosnia \& Herzegovina, 1-12.

Randall, C. and Rollins, R. B. (2009). Visitor Perceptions of The Role of Tour Guides in Natural Areas. Journal of Sustainable Tourism, 17(3): 357-374.

Reisinger, Y. and Steiner, C. (2006). Reconceptualising Interpretation: The Role of Tour Guides in Authentic Tourism. Current Issues in Tourism, 9(6): 481-498.

Sarl, Y. ve Kozak, M. (2005). Turizm Pazarlamasına İnternetin Etkisi: Destinasyon Web Siteleri İçin Bir Model Önerisi. Akdeniz Üniversitesi İktisadi ve İdari Bilimler Fakültesi Dergisi, 5(9), 248-271.

Şahin, D. (2009). Ankara Keçiören Eğitim ve Araştırma Hastanesi Hemşirelerinin Rol Çatışması, Rol Belirsizliği ve Tükenmişlik Durumları. Yayınlanmamış Yüksek Lisans Tezi. Ankara: Ankara Üniversitesi, Sağlık Bilimleri Enstitüsü.

Şengül, S. ve Türkay, O. (2018). Yöresel Mutfak Marka Değeri Algısının Destinasyon Farkındalığı ve Destinasyon Sadakati Üzerindeki Etkisi. Atatürk Üniversitesi Sosyal Bilimler Enstitüsü Dergisi, 22(1): 223-235.

Tekeli, H. (2001). Turizm Pazarlaması ve Planlaması. Ankara: Detay Yayıncllık.

Temizkan, R. (2005). Turist Rehberlerinin Türkiye Imajını Algılamaları. Yayınlanmamış Yüksek Lisans Tezi. Hatay: Mustafa Kemal Üniversitesi Sosyal Bilimler Enstitüsü.

Tetik, N. (2006). Türkiye'de Profesyonel Turist Rehberliği ve Müşterilerin Turist Rehberlerinden Beklentilerinin Analizi (Kuşadası Örneği). Yüksek Lisans Tezi. Balıkesir: Balıkesir Üniversitesi.

Tetik Dinç, N. (2019). Turist Rehberlerinin Rolleri. Ö. Köroğlu ve Ö. Güzel (Ed.), Kavramdan Uygulamaya Turist Rehberlĭgi Mesleği, içinde (ss. 157-190), Ankara: Nobel Akademik Yayıncılık.

Touloupa, S. (2010). Casting Identity in The Cultural Tourism Industry: Greek Tourist Guides in A 'Mission' of Heritage Interpretation, Public Archaeology, 9(1): 4-33. 
Ulusoy Yıldırım, H. ve Avcıkurt, C. (2019). Turist Rehberi Olmak. Köroğlu, Ö. ve Güzel, Ö. (Ed.), Kavramdan Uygulamaya Turist Rehberliği Mesleği, içinde (ss. 75-111), Ankara: Nobel Akademik Yayıncilik.

Usta, Ö. (1992). Turizm. İstanbul: Altın Kitaplar

Weiler, B. and Ham, S. H. (2001). Tour Guides and Interpretation. D. Weaver (Ed.), Encyclopedia of Ecotourism inside (ss. 549-563). USA: CABI Publishing.

Weiler, B. and Ham, S. H. (2010). Development of a Research Instrument for Evaluating the Visitor Outcomes of Face-To-Face Interpretation, Visitor Studies, 13(2): 187-205.

Yamada, N. (2011). Why Tour Guiding is Important for Ecotourism: Enhancing Guiding Quality with The Ecotourism Promotion Policy in Japan. Asia Pacific Journal of Tourism Research, 16(2): 139152.

Yılmaz, H. (2011). Destinasyon Sadakatini Etkileyen Faktörler: Belek Golf Turizmi Uygulaması, Doktora Tezi. Eskişehir: Anadolu Üniversitesi, Sosyal Bilimler Enstitüsü.

Yılmazdoğan, O. C. (2017). Destinasyon Aidiyeti ve Öncüllerinin Destinasyon Sadakati Üzerindeki Etkisi, Doktora Tezi. Eskişehir: Eskişehir Osmangazi Üniversitesi, Sosyal Bilimler Enstitüsü.

Yoon, Y. and Uysal, M. (2005). An Examination of The Effects of Motivation and Satisfaction on Destination Loyalty: a structural model. Tourism Management, 26(1): 45-56. 